\title{
Animal Models Reflecting Chronic Obstructive Pulmonary Disease and Related Respiratory Disorders: Translating Pre-Clinical Data into Clinical Relevance
}

\author{
Lloyd Tanner Andrew Bruce Single
}

Respiratory Medicine and Allergology, Department of Clinical Sciences Lund, Lund University, Lund, Sweden

\section{Keywords}

Chronic obstructive pulmonary disease - Animal models ·

Treatment · Fibrosis · Inflammation

\begin{abstract}
Chronic obstructive pulmonary disease (COPD) affects the lives of an ever-growing number of people worldwide. The lack of understanding surrounding the pathophysiology of the disease and its progression has led to COPD becoming the third leading cause of death worldwide. COPD is incurable, with current treatments only addressing associated symptoms and sometimes slowing its progression, thus highlighting the need to develop novel treatments. However, this has been limited by the lack of experimental standardization within the respiratory disease research area. A lack of coherent animal models that accurately represent all aspects of COPD clinical presentation makes the translation of promising in vitro data to human clinical trials exceptionally challenging. Here, we review current knowledge within the COPD research field, with a focus on current COPD animal models. Moreover, we include a set of advantages and disadvantages for the selection of pre-clinical models for the identification of novel COPD treatments.
\end{abstract}

(c) 2019 The Author(s)

Published by S. Karger AG, Basel

\section{KARGER}

E-Mail karger@karger.com www.karger.com/jin

\section{(c) 2019 The Author(s)}

Published by S. Karger AG, Basel

Karger

Open access

This article is licensed under the Creative Commons AttributionNonCommercial-NoDerivatives 4.0 International License (CC BY NC-ND) (http://www.karger.com/Services/OpenAccessLicense). Usage and distribution for commercial purposes as well as any distribution of modified material requires written permission.

\section{Introduction}

Chronic obstructive pulmonary disease (COPD) is a disease syndrome characterized by an inflammatory airway state induced by environmental stimuli, primarily tobacco smoke and household or industrial air pollution [1-3]. COPD is believed to be a combination of disorders, including chronic bronchitis and emphysema, both of which cause diminished airflow at expiration and are associated with obstructed bronchi $[1,4,5]$. The disease has become a silent killer in low- and middle-income countries because of its slow progression in many patients [68]. Currently estimated to affect 328 million people worldwide, COPD is expected to become one of the leading causes of death within the next 2 decades, although data from outside the USA and European Union are still limited [9-11]. There has been a lack of funding for COPD research compared to that provided for other causes of global mortality and morbidity, despite the major public health problem COPD poses [12].

COPD is characterized by a progressive decline in lung function with intermittent periods of inflammatory bouts, termed exacerbations. The exacerbations are often triggered by infections and result in a significant increase in both morbidity and mortality $[3,13,14]$. These exacerbations are responsible for the majority of

Dr. Lloyd Tanner

Respiratory Medicine and Allergology, Department of Clinical Sciences Lund Lund University, BMC B14

SE-221 84 Lund (Sweden)

E-Mail Lloyd.Tanner@med.lu.se 


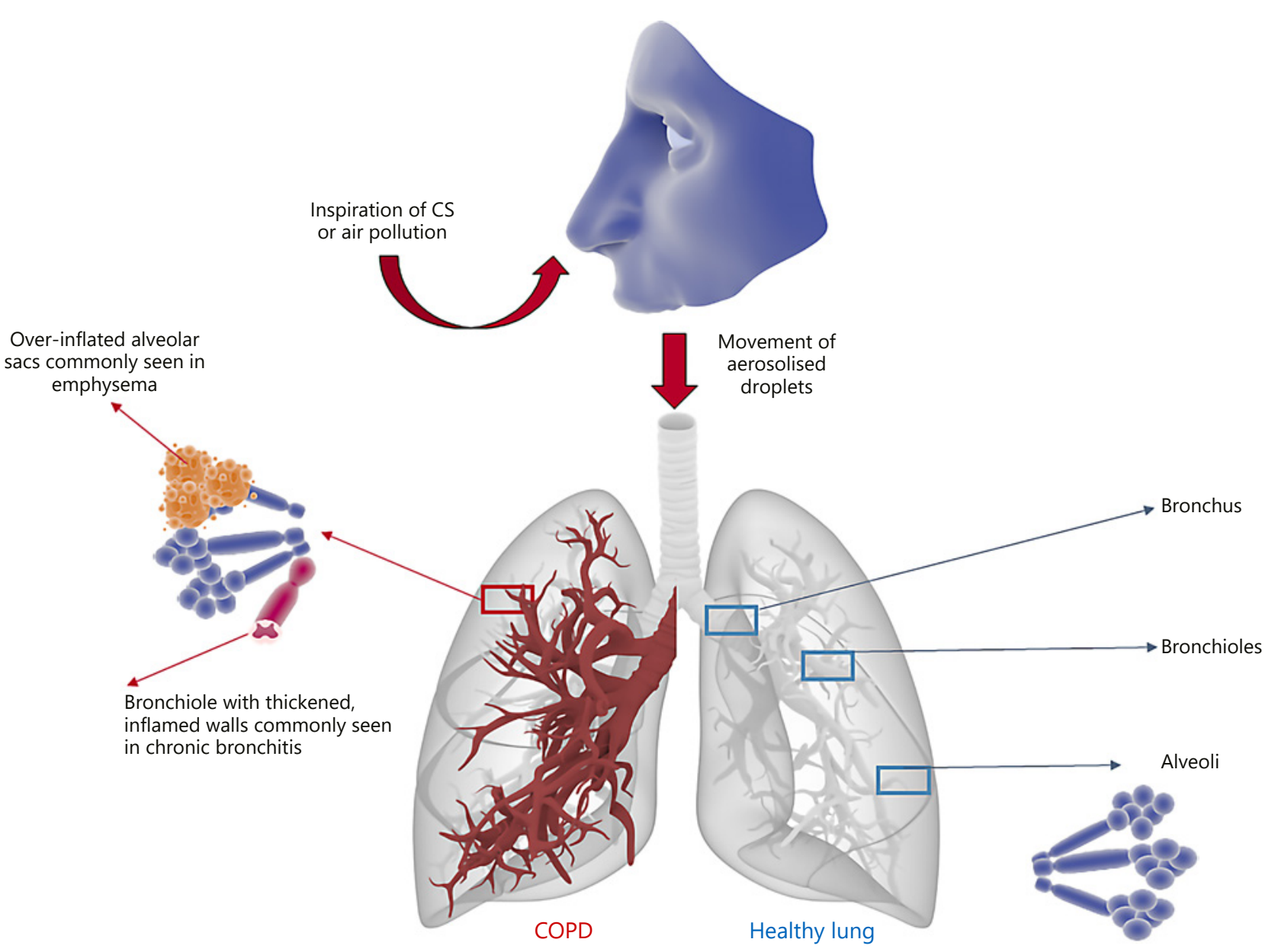

Fig. 1. COPD state versus healthy lung tissue. Inhaled irritants (predominantly CS or fumes from biomass fuels) cause a chronic inflammatory state at different levels of the airways. In the bronchi this may lead to chronic bronchitis, in the bronchioles it causes bronchiolitis, and in the terminal airways and alveoli causes im- paired gas exchange due to emphysema. High proteolytic activity results in mucus-hypersecretion and remodeling. The latter causes emphysema (reducing the area available for gas exchange) and a lack of recoil (limiting the expiratory airflow and causing hyperinflation of the lungs). direct COPD-associated health costs amounting to an estimated USD 30 billion in the USA alone in 2010 [1517]. The economic impact of COPD is not only associated with direct treatment costs, but stretches further as patients are unable to work, resulting in an estimated loss of USD 20 billion to the US economy alone [18]. These costs are expected to increase; as the recently released American Lung Association's "State of the Air Report" highlights, more than $40 \%$ of US citizens live in areas containing "unhealthy" levels of particulate matter $[19,20]$.
The implications of COPD are compounded by the absence of novel drug targets in the area of pulmonary medicine, largely resulting from a lack of knowledge surrounding progression of the disease [21, 22]. Furthermore, disease modeling has proved difficult, as no single in vivo model of COPD fully captures the breadth of symptoms experienced by patients, particularly in the later stages of disease [23-26]. It is important to survey the current COPD research landscape to promote successful models for understanding disease pathology and developing more effective treatment options. 


\section{Methods}

We searched the available literature using various scientific databases including PubMed, ScienceDirect, Google Scholar, Mendeley, Scopus, and Web of Science for English language articles published until the start of July 2019. Articles were excluded if they were unpublished or non-English articles. The number of articles deemed to meet these criteria and included in this review was 312 .

\section{Clinical Presentation}

Clinical presentation of COPD often includes a chronic cough and increased sputum production, and dyspnea, which are all common features amongst patients [27]. These symptoms result from the development of chronic bronchitis and/or emphysema, which are associated with inflamed bronchioles and distended alveolar sacs, respectively (Fig. 1). A strong indication of COPD involves the symptoms above, patient history of predisposing risk factors, and a post-bronchodilator forced expiratory volume after $1 \mathrm{~s}\left(\mathrm{FEV}_{1}\right)$ divided by the forced vital capacity (FVC) value $<0.7[28,29]$. Some have argued that spirometry alone is not an accurate enough predictor of COPD [3032]. In addition, the use of $\mathrm{FEV}_{1} / \mathrm{FVC}$ ratio $<0.7$ to define COPD has shortcomings. For example, it may be prone to over-diagnosis of COPD in individuals over 70 years of age, an age-span where COPD has its highest prevalence. Instead, age-adjusted ratios (lower limit of normal) better reflect COPD among the elderly population [33].

Chronic bronchitis (productive cough that lasts for 3 months or more per year, for at least 2 years) can occur separately or combined with emphysema in COPD, where the latter diagnosis is based on spirometry. Decline in respiratory function is heterogeneous amongst patients, with some experiencing rapid, almost immediate reduction in lung function whilst others experience a more gradual decline [34-39]. The resultant airway damage, lack of elastic lung recoil, and pulmonary obstruction is irreversible, with no cure currently available. Progression of COPD is poorly understood, with patients often requiring supportive medical intervention, such as bronchodilating therapy, corticosteroids, antibiotics, and in severe cases, long-term oxygen therapy. Changes that promote exacerbations are often associated with bacterial or viral infections that cause worsening of the patient's symptoms beyond day-to-day variation, and leave much to interpretation by the prescribing doctor $[32,40]$. This has highlighted the need for personalized precision medical treatment for patients and the development of robust biomarkers for the diagnosis and prediction of these events $[5,32$,
41]. The Global Initiative for Chronic Obstructive Lung Disease (GOLD) 2019 report proposed an updated assessment tool to assign categories of disease severity based on respiratory symptoms and exacerbation history, with treatment options and escalations proposed for each group based on specific clinical presentation $[40,42]$.

\section{Risk Factors for COPD Development}

Smoking is one of the major risk factors associated with COPD development $[43,44]$. Smokers have a higher prevalence of respiratory function irregularities, greater rates of $\mathrm{FEV}_{1}$ decline, and higher rates of mortality than nonsmokers [45]. Furthermore, tobacco smoke exposure at prenatal or postnatal stages of human development is detrimental to lung development, and associated with lung remodeling and risk of pulmonary disease development [46-49]. Air pollution is another reported cause of COPD, implicated in approximately $15-20 \%$ of cases [50]. Exposure to workplace air pollutants such as organic or inorganic dusts, chemical products, and fumes are not fully appreciated as causes of COPD [51]. Sources of household air pollution include chemical/coal fires coupled with poorly ventilated living spaces, leading to an accumulation of polluted air and exposing individuals to prolonged airway insult $[52,53]$. Chronic COPD sufferers experience bacterial or viral infections of the lower respiratory tract, with several studies displaying correlations between COPD exacerbations and infection $[54,55]$. Virus detection rates in patients who have experienced previous exacerbations have been reported to be as high as 64\% [55].

It is not only external factors that influence the COPD development [56]. Host factors including genetic makeup, lung cell hyperresponsiveness to stimuli, and poor lung growth during childhood play crucial roles in the development and severity of COPD $[57,58]$. Additionally, several comorbidities afflict patients with COPD, including cardiovascular disease, muscle weakness, lung cancer, and depression [59-62]. These comorbidities are often associated with smoking and/or genetic predispositions and may appear in the absence of respiratory decline $[27,63]$.

\section{Treatment Options}

Current COPD treatment approaches rely on minimizing exposure to smoke inhalation and reducing the occurrence and severity of exacerbations [64, 65]. Early- 


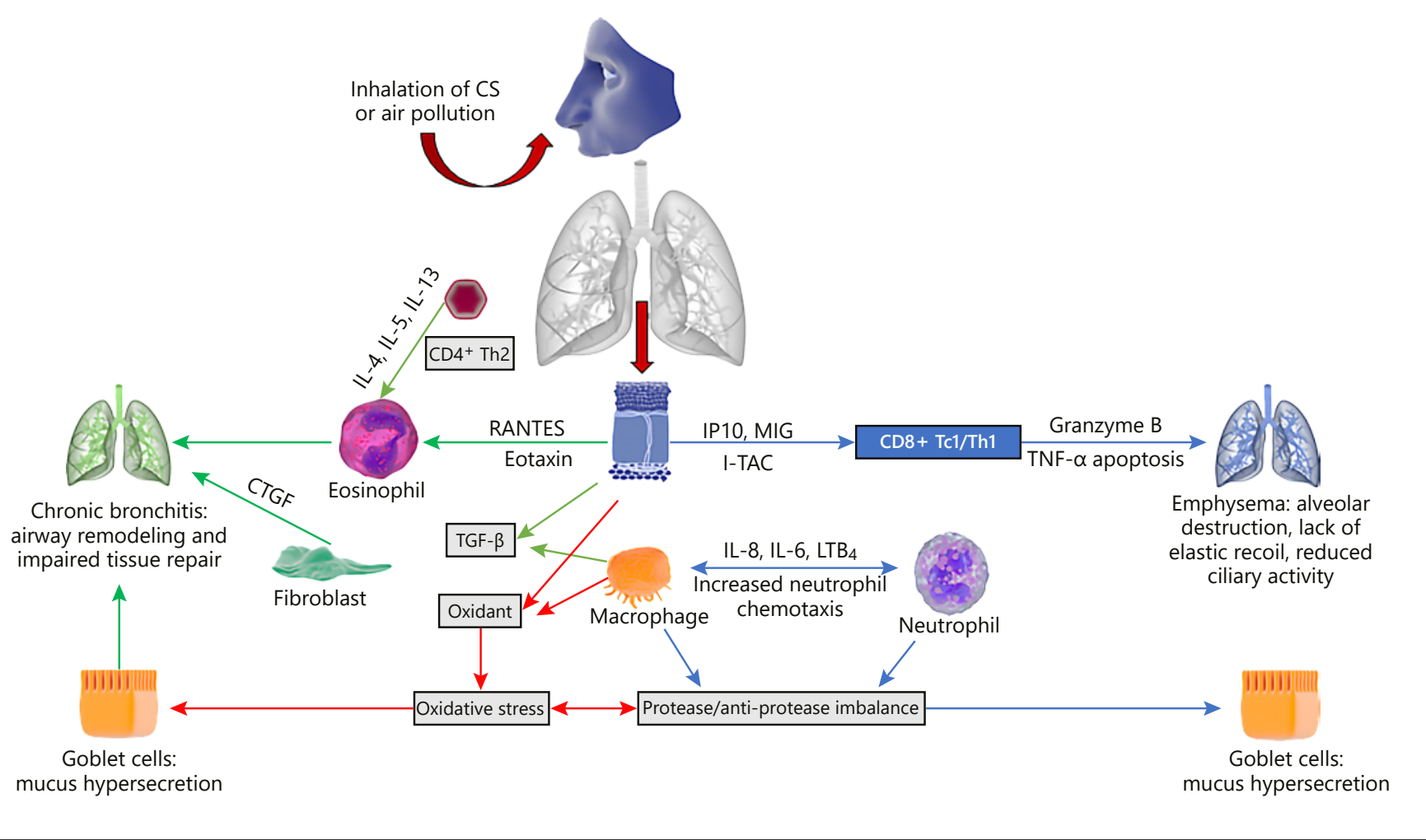

Fig. 2. Molecular mechanisms of COPD development (adapted from Linden et al. [105]). MIG, monokine induced by interferon- $\gamma$; $\mathrm{LTB}_{4}$, leukotriene $\mathrm{B}_{4}$; CTGF, connective tissue growth factor; IP10, interferon- $\gamma$-induced protein 10; I-TAC, IFN-inducible T cell $\alpha$-chemoattractant.

stage intervention is required in order to significantly impact disease progression $[4,5,66]$. Minimizing exposure to both smoking and indoor air pollution decreases the rate of disease progression and is positively correlated with a decrease in mortality $[67,68]$. Physical activity is exceptionally important in reducing exacerbation frequency and mortality rates in patients with COPD [6972]. Other interventions include vaccinations against influenza and pneumococcal infections, as these may reduce the risk of exacerbation events and hospital admission $[73,74]$. Pulmonary rehabilitation is an effective multidisciplinary approach to improving dyspnea and exercise tolerance $[75,76]$.

Pharmacotherapeutic approaches are mainly targeted at improving symptoms, increasing quality of life, and avoiding exacerbations [77]. The primary treatment for airflow limitation is inhalation of long-acting $\beta_{2}$-agonists (LABAs) and long-acting muscarinic antagonists (LAMAs) [29]. LAMA monotherapy is favored over LABA monotherapy in patients with a history of exacerbations $[78,79]$. Fixed doses of LABA/LAMA are available to make drug administration more manageable [80]. Patients who continue to experience symptoms after LABA/ LAMA treatment may benefit from administration of oral phosphodiesterase 4 inhibitors (e.g., roflumilast [81]) or macrolide antibiotics [82, 83]. However, both drug classes are subject to challenging side-effect profiles such as diarrhea and promotion of bacterial resistance, in the case of roflumilast and macrolides, respectively [29]. Considerable efforts have been made in the last decade to develop compounds that control inflammation, with little success thus far [84]. This is largely due to underlying heterogeneity in patient responses to treatment [85-89]. There have been several trials comparing dual bronchodilators with LABA/LAMA monotherapy or triple combination therapies comprising LABA, LAMA, and an inhaled corticosteroid [90-92]. However, few late-phase clinical trials are currently being conducted with many compounds still in the early phases [21].

Treatment for COPD is therefore comparably underdeveloped, with fewer compounds being produced in the last 40 years than for the majority of other disease areas 
[22]. With complex underlying disease heterogeneity and a funding gap, the unmet needs for COPD and other respiratory diseases continue to grow [22].

\section{Molecular Mechanisms of Disease Progression}

COPD is a complex disease involving various inflammatory pathways that have proved difficult to understand in the context of disease progression [36, 38, 93-95]. One theory proposes that protease/anti-protease imbalances and oxidative stress are the main mechanisms contributing to COPD pathogenesis (Fig. 2). Air pollutants such as cigarette smoke (CS) inhaled through the nose and mouth induce airway epithelium and macrophages to release chemotactic factors, including interleukin (IL)-4, 5, 6, 8, and 13 , interferon- $\gamma$-induced protein 10 (IP10), monokine induced by interferon- $\gamma$, and leukotriene $\mathrm{B}_{4}$, which attract and activate key inflammatory cells lining the airway mucosa $[96,97]$. Sustained activation results in airway accumulation of neutrophils, CD8 T cells, and/or CD4 helper T cells $[98,99]$. These cause sustained and abrogated immune responses causing the degradation of elastin, particularly in the alveoli, ultimately resulting in emphysema and lack of elastic lung recoil. The accumulation and hyperactivation of neutrophils result in mucus hypersecretion from goblet cells. High blood eosinophil counts represent an independent risk factor for future exacerbations in patients with COPD [100]. Along with chemotactic factors, macrophages and epithelial cells secrete transforming growth factor- $\beta$, which causes fibroblast proliferation [101]. Additionally, fibroblasts secrete connective tissue growth factor, a chemokine that increases lung epithelial senescence, decreasing cellular regeneration and leading to emphysema [102]. Similarly, granzyme B excreted by CD8+ cells, has been implicated in extracellular matrix degradation and subsequent tissue remodeling associated with emphysema [103, 104].

Other driving factors of COPD include age-associated cellular senescence, as evidenced by the high prevalence among elderly patients with COPD [105]. Evidence suggests emphysema is caused by accelerated ageing of lung tissues and is associated with flawed endogenous antiageing (sirtuins) and autophagy mechanisms [106-108]. This process leads to eventual telomere shortening, cellular senescence, and the development of COPD [109, 110]. Oxidative stress is another key driver of COPD pathogenesis. Reactive oxygen species (ROS) are produced by several cells, including macrophages and neutrophils [111]. ROS activate nuclear factor-kappa B and p38 mitogen-activated protein kinase, thereby increasing protease activity and activating inflammatory genes, whilst decreasing anti-protease activity and promoting elastolysis $[112,113]$.

\section{Establishment of Disease and Exacerbation Biomarkers}

Knowledge in the field of COPD research continues to grow, with an array of animal models currently in use. However, assessing their utility is increasingly difficult in the absence of clinically validated biomarkers that are predictive of both disease onset and progression [114]. Spirometry assessment is currently the most trusted diagnostic tool; however, it does not account for the heterogeneity of symptoms seen amongst patients. Patients with stable spirometry readings are still subject to cardiac arrest and muscle weakening, the most common aspects of COPD mortality and morbidity, respectively [115].

Despite the critical need for novel biomarkers, very few clinical studies have linked disease outcome (morbidity/mortality) with any reliable biomarkers [116-118]. Patient studies have shown correlations between generalized inflammatory markers such as increased white blood cell count $[119,120]$, TNF- $\alpha[120,121]$, IL-6 [121, 122], C-reactive protein [123], and IL-8 [120, 124], but few show significant correlations with the prediction of exacerbation onset $[125,126]$. Few biomarkers have been approved for use in clinical trials, with only plasma fibrinogen and soluble receptor for advanced glycation end products (sRAGE) approved by the US Food and Drug Administration (FDA) [127-129]. Correlations in animal models have also been investigated, revealing associations between disease state and plasma fibrinogen and sRAGE levels [130-133]. Novel studies investigating volatile organic compounds as breath-based biomarkers using gas chromatography have provided new insight in the field [134]. The establishment of proteomic, genomic, and metabolomic platforms continues to deliver possible biomarker alternatives [135], although these cannot be implemented without proper validation in clinical trials.

\section{In vitro Models}

In vitro models facilitate the study of selected physiological processes within a controlled environment before confirming the hypothesis in a more complex in vivo environment $[136,137]$. The human lung features a range 
Table 1. Summary of advantages and disadvantages of using various animal models to understand COPD

\begin{tabular}{|c|c|c|c|}
\hline Animal model & Advantages & Disadvantages & $\begin{array}{l}\text { COPD } \\
\text { studies } \\
\text { (Ref. No.) }\end{array}$ \\
\hline Rat & $\begin{array}{l}\text { Higher lung surface area compared to other } \\
\text { rodents } \\
\text { Greater size makes procedures easier } \\
\text { Fibrotic depositions following smoke exposure }\end{array}$ & $\begin{array}{l}\text { Lower genetic similarity to humans } \\
\text { Monopodial airway structure } \\
\text { Higher mucociliary clearance } \\
\text { No goblet cells } \\
\text { Fewer mucosal glands }\end{array}$ & $312-316$ \\
\hline Hamster & $\begin{array}{l}\text { Higher nitric oxide production } \\
\text { More important ciliated epithelium } \\
\text { Moderate goblet cell numbers }\end{array}$ & $\begin{array}{l}\text { Low availability of species-specific reagents } \\
\text { Low genetic diversity } \\
\text { Aggressive behavior (handling more } \\
\text { challenging) }\end{array}$ & $\begin{array}{l}263,322- \\
324\end{array}$ \\
\hline Rabbit & $\begin{array}{l}\text { Similar response to histamines and antigens } \\
\text { More similar lung structure compared to rodents } \\
\text { Larger size (procedures easier) } \\
\text { Fairly docile } \\
\text { Longer lifespan (longer studies) }\end{array}$ & $\begin{array}{l}\text { Susceptibility to non-experimental disease } \\
\text { No cough reflex } \\
\text { Monopodial lung structure } \\
\text { Different mucus composition }\end{array}$ & $325-328$ \\
\hline Pig & $\begin{array}{l}\text { Large number of diverse breeds } \\
\text { Organ-to-body weight similar to humans } \\
\text { Similar lung structure to humans }\end{array}$ & $\begin{array}{l}\text { Narrow mouth (intratracheal procedures } \\
\text { challenging) } \\
\text { High housing costs }\end{array}$ & 334,335 \\
\hline Sheep & $\begin{array}{l}\text { Docile } \\
\text { Dichotomous lung structure } \\
\text { Similar mucus content to humans } \\
\text { Similar response to smoke inhalation }\end{array}$ & $\begin{array}{l}\text { Disease progression poorly understood } \\
\text { Few species-specific reagents } \\
\text { High risk of vomiting during procedure } \\
\text { Need for human breathing devices }\end{array}$ & $\begin{array}{l}286,288 \\
336,337\end{array}$ \\
\hline $\begin{array}{l}\text { Non-human } \\
\text { primate }\end{array}$ & $\begin{array}{l}\text { Dichotomous airway } \\
\text { Genetic similarity } \\
\text { Human reagents can be used }\end{array}$ & $\begin{array}{l}\text { Skilled handling required } \\
\text { Specialized equipment } \\
\text { Higher costs } \\
\text { Higher ethical implications }\end{array}$ & $\begin{array}{l}102,338- \\
343\end{array}$ \\
\hline
\end{tabular}


of different cell types including epithelial cells, macrophages, fibroblasts, smooth muscle cells, and pathogenic cells that exist in a milieu of microenvironments [138, 139]. Many COPD mechanisms have been tested in immortalized cell lines, such as BEAS2B and A549, derived from human bronchial epithelium and human lung alveolar epithelium, respectively [140]. Although these cells do not offer direct representations of the human lung environment, they offer less variability and are easier to maintain and manipulate in culture, whilst still maintaining lung-derived primary cell features [141]. COPD involves the interaction of the respiratory, immune, and cardiovascular systems. Understanding disease pathology and progression requires the use of co-cultured cells in either monolayers or spheroids from each system to more accurately represent the in vivo environment $[142,143]$.

Primary cells obtained directly from patients through lung resections, bronchoalveolar lavage fluid extraction, and biopsies offer a more patient-specific phenotype compared to immortalized cell lines [142, 143]. The utility of these cell lines is increased when used as structurally representative models such as air-liquid interface (ALI) cultures, which facilitate cell differentiation and the development of structural features such as cilia [144146]. A noteworthy drawback of using in vitro cultured cells is their removal from the extracellular matrix and milieu of inflammatory cells, potentially skewing readouts and resulting in poor translational value for clinical application [143]. This may be minimized by culturing cells on biorelevant matrices [147], limiting passage number, and ensuring cell morphology consistency [143].

Alternatives to this approach include ex vivo lung slices that retain lung structural and organizational properties [148], and other perfusion models which allow for extracellular matrix and tissue factor involvement [149, 150]. Three-dimensional (3D) organoid models have also been proposed for possible inclusion in biomedical research efforts [151-153]. Several models involving undifferentiated bronchial epithelial cells have been established and are commercially available, including EpiAirway ${ }^{\circledR}$ (MatTek Corporation, Ashland, MA, USA) and MucilAir $^{\mathrm{TM}}$ (Epithelix Sarl, Geneva, Switzerland). These systems offer 3D human lung organoid cultures that are co-cultured or stimulated with smoke or alternative stimulants to induce inflammatory or fibrotic phenotypes similar to those seen in COPD, asthma, and pulmonary fibrosis. These cells can be cultured for a significantly longer time than ex vivo lung and perfusion models [147]. Benam et al. [154] demonstrated an innovative microfluidic system incorporating endothelial and epithelial cells exposed to airflow and culture medium, respectively. This system provided a means to study immune cell recruitment to the airways [154]. This model was further expanded to the lung-on-a-chip model by incorporating a flexible membrane, which mimics inspiratory and expiratory movements, and produces ALI-induced features $[155,156]$. Despite several advantages offered by in vitro/ ex vivo approaches, there are limitations to experimental reproducibility due to variations in human tissues/cells, obtaining tissues from individuals with underlying diseases, the limited availability of human tissues, and the interlaboratory differences in cell culture protocols, particularly involving 3D models [147]. With the incorporation of tissue printing technologies and the greater understanding of stem cell biology, the development of labgrown, standardized human tissues may not be too far in the future $[157,158]$.

\section{Animal Models}

Although the 3 Rs (reduction, replacement, and refinement) should always be implemented where possible, it is important to confirm in vitro findings in a wholelung environment in a pre-clinical animal model prior to clinical trials. It is vital to interrogate an organism at multiple levels including molecular, cellular, organ, and whole organism to fully comprehend the intricacies of a disease [159]. There are a number of small animal models that adequately recapitulate individual features of COPD and choosing the most representative model has become an integral factor in the development of novel COPD treatments [160]. Current models used to investigate COPD, which display a range of similar anatomical and physiological responses to COPD-inducing stimuli in humans, include rodents, dogs, guinea pigs, non-human primates, and sheep (as reviewed in [23, 161-163] and summarized within Table 1). Examples of COPD studies in animals range from the discovery of porcine pancreatic elastase-induced emphysema in murine and hamster lungs $[164,165]$, to the discovery of airspace enlargement induced by CS in mice, rats, and guinea pigs $[166,167]$.

Several experimental models of COPD are available, each with their own advantages and disadvantages with many models replicating different stages of disease progression [168]. Due to complex COPD pathophysiology, it is difficult to capture both chronic bronchitis-related or emphysematous changes in a single model. Multiple biologically relevant procedures may be used to recapitulate aspects of COPD (Fig. 3). 


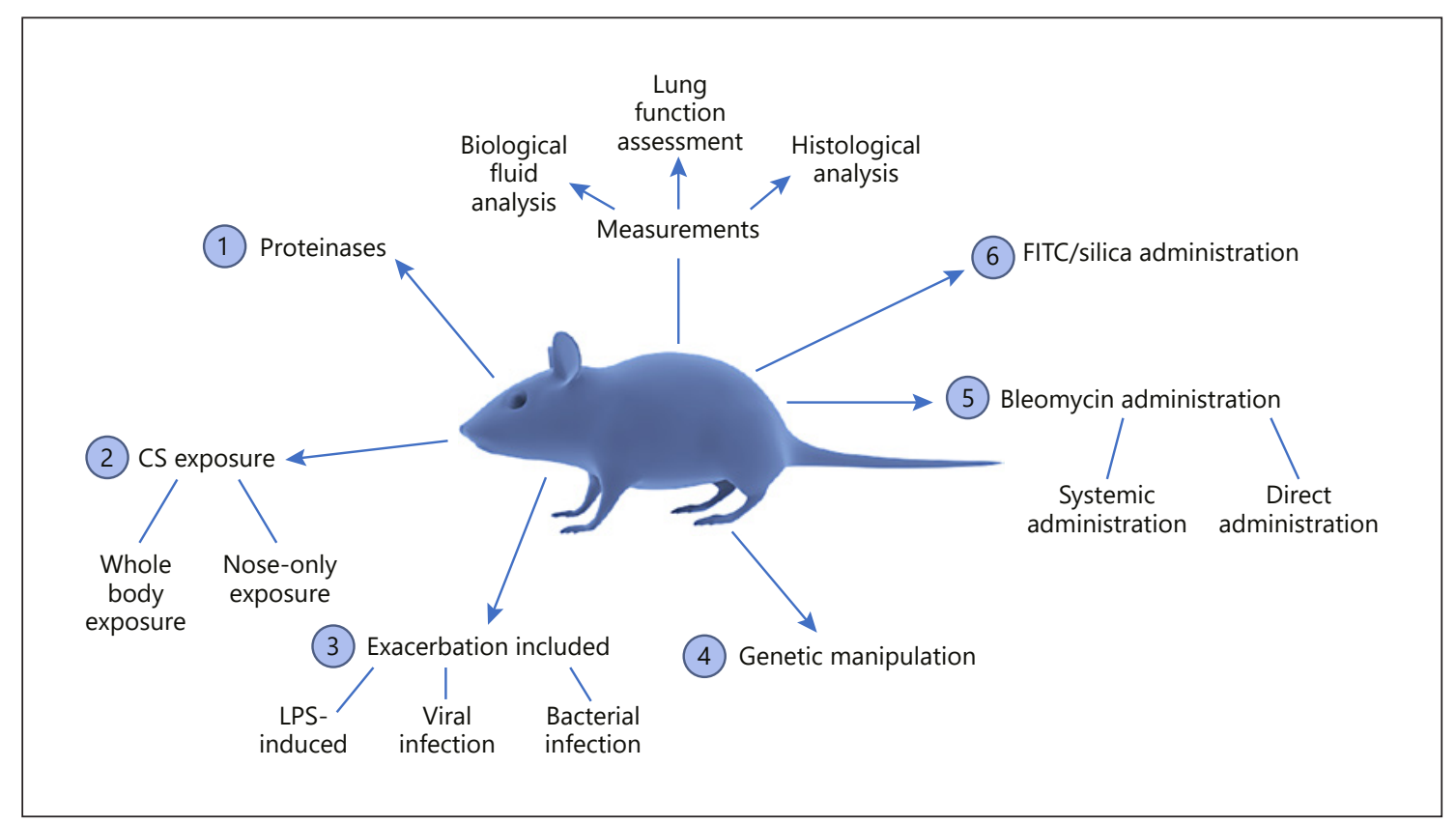

Fig. 3. Commonly utilized animal models of COPD/fibrosis.

\section{Elastase Instillation}

The tracheal installation of tissue-damaging agents was one of the first models to be adapted for studying lung damage [169]. In 1963, Laurell and Eriksson [170] described the development of emphysema in elderly patients deficient in $\alpha_{1}$-antitrypsin, causing a buildup of elastase. This became the basis for the development of several elastase models, the earliest described by Gross et al. [171] who demonstrated that the plant elastase, papain, induced emphysematous changes in rats. Elastase is the most commonly used proteolytic enzyme (porcine pancreatic elastase or human neutrophilic elastase) to induce and perpetuate an inflammatory response in the mouse [172]. The attractiveness of the model is that a single dose of elastase results in immediate loss of alveolar wall structure. However, the narrow dosing window of elastase is restrictive, with concentrations below the recommended dose providing no change in lung structure and concentrations above a threshold level resulting in severe pulmonary hemorrhage and mortality in multiple species [173, 174]. Although elastase involvement in COPD has been shown, the direct instillation of elastases into an animal model offers little understanding of disease pathogenesis [175]. The model reduces the impact of immune cell involvement, a vital aspect in human COPD pathophysiology, and instead induces "artificial" tissue destruction $[176,177]$. These models may be more relevant for the initial assessment of alveolar damage mechanisms. Recently, Gu et al. [178] demonstrated the use of a murine model of anti-elastin autoimmunity resulting in emphysema that could be used to examine the role of immune tolerance in diseases, such as COPD, and enhance the clinical relevance of elastase-based models.

\section{Genetic Manipulation}

Several studies have demonstrated the role of genetic factors in COPD development $[179,180]$, with naturally occurring mutant murine models $[165,181]$, conditional transgenic [182, 183], and transgenic animals [184-186] developing emphysema. Murine models are favored over other animal models due to their large litter size and fast reproductive cycle, which speeds up the selection of favorable genetic traits that can be used in disease models [187]. Prior to conducting research involving transgenic animal models, one should always consider the translational relevance of potential findings to the human disease context. An example of a successful approach can be seen in matrix metalloproteinase-12 (MMP-12), which is essential for the development of emphysema in mice exposed to CS, with MMP-12 associated with risk of COPD in adult smokers [188-191]. 


\section{CS Exposure}

CS exposure is one of the major risk factors for the development of COPD and is a model which many groups have adopted [162]. The protocols for smoke exposure in mice vary greatly with differences in length, frequency, and number of CS exposures, as well as the type of exposure and cigarette being used [26]. Additionally, the method of smoke production is a critical factor and is described as either mainstream smoke, produced by the act of puffing or inhalation, or sidestream smoke, which is generated passively from the burning of cigarettes [26]. These different methods of smoke generation influence smoke component concentrations but seemingly do not significantly influence the animal disease state [192].

The differences between the method of smoke exposure, either whole-body or nose-only systems, has also been highlighted as a potential source of variation in mouse disease phenotypes $[25,168]$. Whole-body CS exposure involves animals being exposed to varying concentrations of $\mathrm{CS}$ in a chamber. A downside to this approach is that animals retain constituents of CS on their fur which is ingested and can influence results [168]. This is alleviated using the nose-only method, whereby animals are exposed to CS using a restraining cone. The use of CS nose-only models eliminates most fur exposure, allowing concentrations of $\mathrm{CS}$ to be regulated. However, nose-only exposure is more stressful for the animal, sometimes resulting in weight loss due to prolonged confinement in restraining devices [168]. It is suggested that nose-only exposure produces more pronounced mouse phenotypic changes that may be more similar to human emphysema $[26,168]$.

Interspecies differences influence the development time of emphysematous phenotypes following CS exposure, with many animals taking 4-6 months [193] to display signs of disease whilst rats produce a similar phenotype in 2 months [194] due to physiological differences discussed later in this review. The disadvantages to using CS exposure include the resistance of some species, such as mice, to CSinduced neutrophilic inflammation and damage, which ceases after CS exposure is discontinued $[176,195]$. As such, many have commented that the murine model of CS exposure fails to capture clinical disease complexities [177].

\section{Lipopolysaccharide Exposure}

Lipopolysaccharide (LPS) is a Gram-negative bacterium cell wall component, present in air pollution and organic dusts [196, 197]. LPS in COPD patient bronchoal- veolar lavage fluid has indicated a potential role for LPS in disease progression $[198,199]$. A single LPS exposure induces pulmonary inflammation in many animals, characterized by neutrophil and macrophage influx [200205]. Chronic exposure to LPS induces structural changes to the murine and guinea pig lung, which persist after LPS exposure has ceased, mediated primarily by increases in TNF- $\alpha$, IFN- $\gamma$, and IL-18 [203, 206-210]. The advantages of using LPS-induced inflammation and fibrosis models over other models such as CS include the relatively short time frame to achieve pathological features of COPD [211]. The changes reported in animal LPS studies are equivalent to features seen in mild human COPD [168].

This distinction makes the LPS model more valuable for understanding exacerbation-related COPD mechanisms [212]. Bacteria isolated from the lungs of patients immediately after exacerbation events are predominantly Gram-negative $[213,214]$. Several groups have attempted to replicate COPD exacerbations in animals by combining COPD-induced animals (using CS or other induction agents) with exposure to bacterial/viral infection or LPS, often increasing the severity of emphysematous changes [168, 215-217].

\section{Bleomycin Administration}

The most widely used method for fibrotic lung damage induction is via bleomycin administration, a chemotherapeutic agent, known to induce lung fibrosis in approximately $10 \%$ of humans [218]. In animal models, bleomycin may be administered using a number of different procedures, each leading to different disease phenotypes. C57BL/6 mice appear to be more susceptible to bleomycin-induced fibrosis, with $\mathrm{BALB} / \mathrm{c}$ mice more resistant due to differential cytokine expression [219].

The most common method of bleomycin administration consists of a single intranasal or intratracheal dose of bleomycin, with analysis 3-4 weeks later. Bleomycin causes acute tissue damage in lung regions where the solution permeates, followed by localized inflammation which peaks after 7 days, and subsequent fibrosis [220]. Intratracheal/intranasal bleomycin-induced fibrosis is reproducible, only affects the lungs, and is utilized by many research groups globally, allowing the generation of comparative results [221, 222]. Inflammation-associated fatalities reported using this model are common, with bleomycin deposition occurring predominantly within the central lung, modelling an acute lung injury or acute 
respiratory distress syndrome akin to the human phenotype [223].

Systemic bleomycin administered intravenously or subcutaneously results in more homogenous, distal patterns of lung fibrosis throughout the lung. Unfortunately, several bleomycin administrations are required over a longer time period to achieve this fibrotic effect [222]. The systemic administration of bleomycin results in less inflammation compared to direct intratracheal administration and is less predictive of localized fibrotic conditions such as idiopathic pulmonary fibrosis [220].

\section{Fluorescein Isothiocyanate and Silica Administration}

Fluorescein isothiocyanate (FITC) induces a similarly localized pattern of inflammation in mice compared to bleomycin, which persists for up to 5 months after administration, comparably longer than most other administered substances [220]. FITC is also fluorescent, allowing FITC-exposed lung regions to be easily imaged [222]. However, the FITC model does not produce robust results due to difficulties in FITC preparation, causing groups to utilize other models [220].

Silica particles induce similar responses in the lungs of humans and mice, with fibrotic remodeling persisting after silica administration ceases [220]. As with bleomycin, this phenotype appears more readily in C57BL/6 mice [220]. The model takes between 30 and 60 days to establish measurable fibrotic changes in mice, longer than bleomycin and several other models [222].

\section{Animals Currently Included in COPD Studies}

\section{Mice}

Mice offer several advantages over other species, including low housing costs, relatively short breeding time in comparison to higher species, extensive knowledge of the genome [224, 225], ease of genetic modifications [160, 226], and heterogeneity of reactions to exogenous stimuli amongst different murine strains [177, 224, 227]. CS is most commonly used to induce COPD in mice $[25,176$, 195, 228-230]. Other models rely on the administration of LPS or proteases [195, 229], or the use of genetic alterations [187]. These models are able to replicate earlystage COPD symptoms including small airway and vascular remodeling, mucus hypersecretion, and increased lung inflammation [231]. However, modeling the more severe stages of COPD, including chronic bronchitis and debilitating lung function decline, have been more arduous as the mice either recover from the symptoms or succumb to disease before disease parameters can be adequately assessed [232].

It is important to note lung anatomical differences between humans and mice, with the latter possessing fewer submucosal glands and only six to eight pre-bronchioles before termination, with further anatomical differences reported elsewhere $[177,233]$. Importantly for respiratory studies, humans inhale smoke through the mouth predominantly, whilst mice are obligate nose-breathers [234]. Arterial oxygen tension and mean arterial pressure are exceptionally difficult to measure considering the animal's small size, although full-body plethysmography allows for some of these challenges to be overcome [234, 235]. Considering these differences, it is important to incorporate multiple animal models to answer different biological questions, as an all-encompassing single model is still not available.

\section{Rats}

Rats have been used less frequently to model COPD than mice, partly because of their reported resistance to the development of COPD symptoms [25, 176, 236]. Although rats possess a less analogous genome to humans than mice [237], there are slight advantages to using the rat model in the study of COPD. Anatomically, the rats' larger body size facilitates biological sampling, with more straightforward surgical and lung function measurement procedures [238, 239]. Rats also harbor larger alveoli, with a mean linear intercept of $100 \mu \mathrm{m}$ and an air-blood barrier size of $0.38 \mu \mathrm{m}$, although these are still not comparable to those of humans $(210$ and $0.62 \mu \mathrm{m}$, respectively) [240].

The bronchiolar branching pattern of both mice and rats is monopodial (single continuous bronchus with multiple emanating bronchioles) whilst it is dichotomous (the bronchus diverges into two bronchioles, which subsequently branch into two smaller airways) in humans, which may lead to differences in particulate matter distribution within the lungs [241]. Mucociliary clearance is markedly increased in rats with average particulate matter cleared from the lung within $8 \mathrm{~h}$, although this process can take in excess of $24 \mathrm{~h}$ in humans [240]. Other disadvantages to using rat models include the fact that they are obligate nose breathers [235], possess no goblet cells [23], and possess significantly fewer mucosal glands than larger animals, rendering chronic bronchitis modeling difficult [242]. 


\section{Guinea Pigs}

Guinea pigs have been studied extensively in respiratory experimentation, particularly in the field of tuberculosis [243-245]. Guinea pigs mount inflammatory responses similar to those of humans, thus providing more accurate interspecies comparisons [246]. The development of emphysematous lesions, lack of elastic lung recoil, and inability to gain weight have also been recorded in this model [247]. Guinea pigs have comparably smaller lungs than other rodents as they possess a larger heart [248]. The lungs are divided into seven lobes with a human-like dichotomous bronchiolar structure [248, 249]. The tracheal epithelium of the guinea pig is more uniformly arranged than that seen in mice and comprises mucus glands and goblet cells in the larger airways [23]. Upon CS exposure, guinea pigs exhibit anthropomorphic responses such as acute neutrophilia, increased epithelial permeability, sustained monocyte recruitment, mucus secretion, and alveolar destruction [23, 250]. Viral infection also appears to elicit similar neutrophil recruitment in guinea pigs, highlighting the utility of this model for exacerbation [251]. The major disadvantage of this model is the axon reflex, which plays a limited role in human airways but controls the majority of responses to lung injury in the guinea pig [245]. The lack of available inbred strains also severely restricts the potential for variation in disease phenotype [245]. There are also fewer commercially available cytokine and immunological markers for guinea pigs [245, 252]. Blood collection and the administration of substances to guinea pigs is more challenging because of their lack of a tail and thick skin, whilst the presence of an elongated soft palate may hinder intratracheal procedures $[166,253$, 254]. The guinea pig is a docile animal, making handling and procedures easier than that with other rodents [255].

\section{Hamsters}

Hamsters are the fifth most used laboratory animal (behind mice, rats, rabbits, and guinea pigs $[23,160]$ ), and are more commonly used for vaccine production and therapeutic studies [256-258]. Hamsters produce significantly more nitric oxide than other rodents following lung injury [259] and have been used in several studies investigating both CS exposure [260-263] and diesel smoke exposure $[264,265]$. In addition, hamsters have ten times more non-ciliated bronchiolar cells than other rodents and moderate numbers of goblet cells [266, 267].

As with other rodents, the hamster bronchiolar branching pattern is monopodial [266]. As the hamster is not commonly used, the issue of disease-specific reagents such as cytokine and immunological markers is a problem
[268]. The hamster can be more aggressive than many other rodent species because of its nocturnal and territorial nature, making handling more challenging [269].

\section{Rabbits}

Rabbits are phylogenetically closer to humans than other rodents as reflected by closer anatomical, physiological, genetic, and biochemical similarities [270, 271]. Rabbits have been used to study a number of pulmonary diseases including obstructive airway disorders, cystic fibrosis, and embolic stroke [272-274]. Furthermore, airway inflammatory responses to stimuli such as histamines and antigens show comparable responses in rabbits and patients suffering with asthma [275]. The rabbit allergy model, which involves the sensitization of young rabbits to antigen, has shown sensitivity to similar asthmatic drugs such as B-adrenoreceptor agonists, corticosteroids, and phosphodiesterase inhibitors [275].

The disadvantages of using rabbits as experimental animals include their propensity to bacterial and viral infection during non-sterile procedures [276]. Furthermore, the inability of the rabbit to cough, its monopodial lung structure, and different mucus composition compared to that of humans make this a poor model for CS inhalation studies [271, 277-279]. However, the long lifespan and large body size make the rabbit attractive to long-term lung function studies, although this is accompanied by higher housing costs [275].

\section{Dogs}

Experimental dog models weigh between 10 and $20 \mathrm{~kg}$ and possess larger airways than rodent and lagomorph models, thus allowing targeted delivery of disease-causing reagents or treatments to one lung, whilst allowing the other lung to serve as a control to minimize animal usage and interanimal variability $[280,281]$. Dogs also possess a large mouth, allowing for easier pulmonary delivery system studies $[282,283]$. The lung structure of the dog is monopodial [284], with higher numbers of alveoli and more human-like epithelial microstructure than rodents [285]. The dog is one of few animal models that exhibits a cough reflex, an important physiological symptom of COPD [281]. Respiratory studies using dogs are hampered by increased costs and limited species-specific reagents [160].

\section{Sheep}

Sheep are fairly docile laboratory animals weighing $35-55 \mathrm{~kg}$ [160]. Irregular dichotomous branching of the bronchioles combined with similar mucus production 


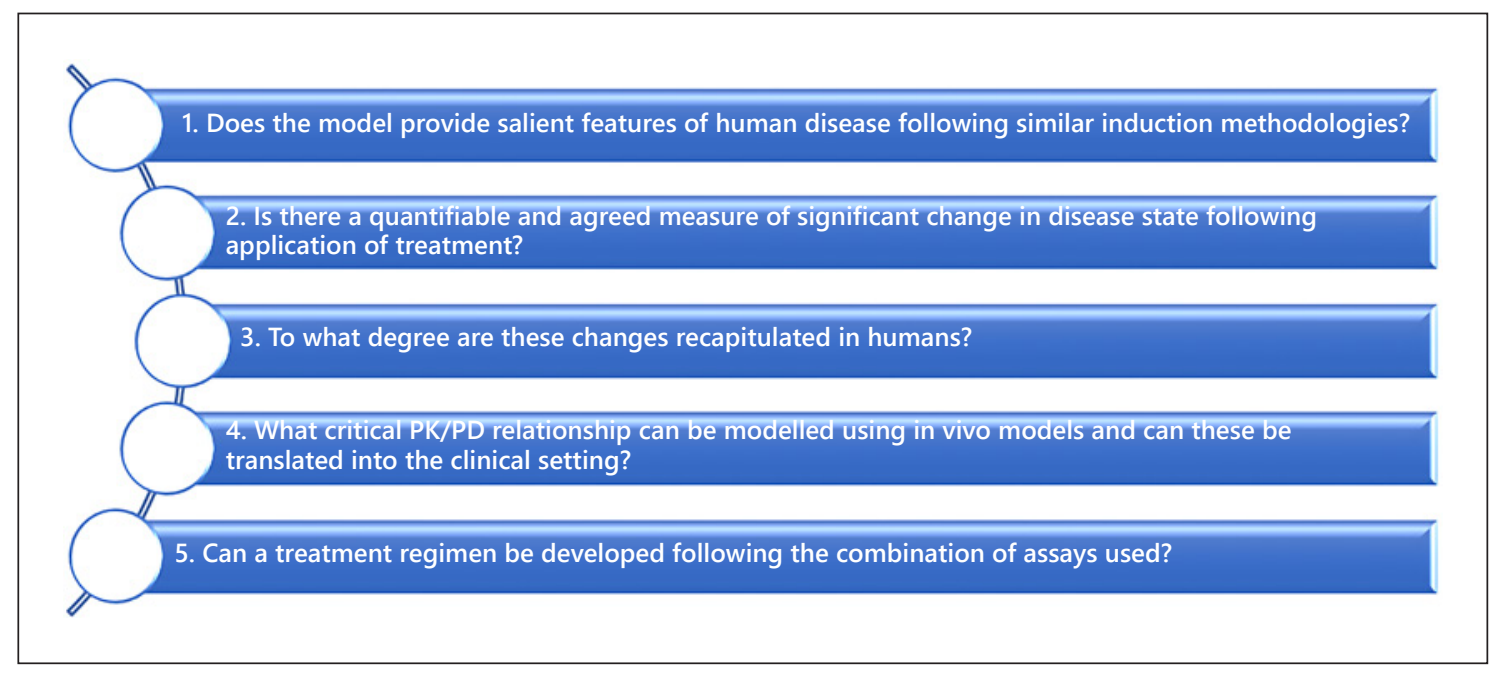

Fig. 4. Determining the clinical importance of assay inclusion in a drug discovery cascade. PK, pharmacokinetic; $\mathrm{PD}$, pharmacodynamic.

and epithelial cell distribution in the airways lead to human-like responses following smoke exposure [286-288]. However, COPD progression in sheep is poorly understood due to the limited array of available reagents to study the specific inflammatory environment of the sheep respiratory tract [287]. Further drawbacks to the sheep model include an increased risk of vomiting and the need to use human devices because of the similarity in breathing parameters, which increases the costs of experimentation but may also allow human-like inhalation devices and techniques to be trialed [287-290].

\section{Pigs}

There are over 500 known breeds of pig, presenting a wide variety of experimental variables with which to work [291]. Large pigs (100-115 kg) have organ-to-body weight ratios similar to those of humans and very similar lung structures to humans, with only primate lungs showing more similarities [292]. The major downfall of the experimental pig model is the exceptionally narrow mouth opening, making intubation and intratracheal procedures very challenging, often requiring the use of modified human equipment $[293,294]$. Furthermore, extensive housing requirements increase the cost of using pigs in respiratory studies [295].

\section{Non-Human Primates}

Non-human primates range in size from $130 \mathrm{~g}$ to 200 $\mathrm{kg}$, with the closest physiological representation to humans being the chimpanzee. However, chimpanzees are endangered and therefore alternative animals such as macaque monkeys are more commonly used [296, 297]. In particular, the rhesus macaque (Macaca mulatta) possesses the most similar lung structure to humans, with regular dichotomous branching of the bronchioles and extensive alveoli distribution [298, 299]. Microstructures of the rhesus macaque also present striking similarities to humans, with ciliated, goblet, and basal cells lining the airways in analogous patterns [300, 301]. Genomic similarities present the added advantage of using human reagents in this model, allowing easier associations between species to be made [302].

The primate model requires a greater degree of skilled handling as the animals may anticipate procedures, increasing levels of undue stress. Specialized equipment and techniques are required to anaesthetize and perform procedures on the animals, which comes with increased housing costs and greater ethical implications.

\section{Modelling Comorbidities of COPD}

Patients with COPD are prone to co-morbidities such as lung cancer, osteoporosis, cardiovascular diseases, and cachexia in late-stage disease [303]. This highlights the multifactorial nature of COPD, which should be considered when designing models to fully understand disease interplay $[116,304]$. Several groups have already modified CS smoke-induced animal models to mimic pulmonary hypertension [305-307], muscle atrophy [308], and 
atherosclerosis [309]. These models, which incorporate co-morbidities, could offer a more holistic understanding of COPD.

\section{Selecting a Model for COPD}

The advantages and disadvantages of various COPD models have been highlighted throughout this review but selecting the most relevant model has not yet been addressed. The chosen model should answer key questions in the drug discovery process (Fig. 4) and fit into a highthroughput assay cascade that addresses various aspects of disease physiology.

The salient features of disease physiology should be predicted by each model. Models that fail to reproduce some aspect of human physiology do not offer any relevance in this treatment discovery algorithm and should be excluded. Similarly, the value of a model is greatly diminished if it does not show a measurable change following treatment. The translation of these findings in pre-clinical models to clinical trials is paramount to the process of novel treatment discovery. Crucially, following pre-clinical testing, the compound or treatment regimen should be safe and effective in patients as many hours and significant monetary investments are dependent upon this.

If the selected model does not fulfill these criteria, subsequent reassessments should take place to replace or refine the model in order to make it more predictive of the clinical environment. The testing cascade used to assess novel treatments should be optimized from the initial design of the molecule, pharmacochemical assessment, in vitro testing, testing in predictive animal models, and finally into human clinical trials. Refinement is key to developing a cost-effective treatment in the shortest period of time.

\section{Conclusion}

Significant progress has been made in the use of animal models since the initial introduction of animal experimentation. However, no single model of COPD captures all aspects of the human disease. The animal models discussed in this review mimic specific disease aspects without fully reproducing the broad spectrum of human COPD phenotypes. This points to a need for the careful selection of animal models, which sufficiently capture the most pertinent clinical features of disease, allowing for the performance of more predictive pharmacokinetic/ pharmacodynamic analyses for clinical translation. This will strengthen our knowledge of current molecular mechanisms of COPD and allow for the provision of better treatments. With the inclusion of relevant animal models and newer technologies as outlined here, the treatment of COPD and other lung diseases could be closer than expected.

\section{Acknowledgements}

This work was supported by the Swedish Heart and Lung Foundation and the Alfred Österlund Foundation.

\section{Disclosure Statement}

The authors have no conflicts of interest to declare.

\section{Author Contributions}

L.T. and A.B.S. contributed to the conceptual design for this review. L.T. wrote the initial draft of the manuscript whilst A.B.S. edited and revised the manuscript.

\section{References}

1 Eisner MD, Anthonisen N, Coultas D, Kuenzli N, Perez-Padilla R, Postma D, et al.; Committee on Nonsmoking COPD, Environmental and Occupational Health Assembly. An official American Thoracic Society public policy statement: novel risk factors and the global burden of chronic obstructive pulmonary disease. Am J Respir Crit Care Med. 2010 Sep;182(5):693-718.

2 Karayama M, Inui N, Yasui H, Kono M, Hozumi H, Suzuki Y, et al. Physiological and morphological differences of airways between COPD and asthma-COPD overlap. Sci Rep. 2019 May;9(1):7818.
3 Barnes PJ, Burney PG, Silverman EK, Celli BR, Vestbo J, Wedzicha JA, et al. Chronic obstructive pulmonary disease. Nat Rev Dis Primers. 2015 Dec;1(1):15076.

4 Koo HK, Vasilescu DM, Booth S, Hsieh A, Katsamenis OL, Fishbane N, et al. Small airways disease in mild and moderate chronic obstructive pulmonary disease: a cross-sectional study. Lancet Respir Med. 2018 Aug; 6(8):591-602. Available from: http://www. sciencedirect.com/science/article/pii/ S2213260018301966
5 Russell DW, Wells JM. COPD ground zero: small airways rather than alveoli as the initial site of injury. Lancet Respir Med. 2018 Aug; 6(8):568-9. Available from: http://www.sciencedirect.com/science/article/pii/ S221326001830290X

6 Croxton TL, Weinmann GG, Senior RM, Hoidal JR. Future research directions in chronic obstructive pulmonary disease. Am J Respir Crit Care Med. 2002 Mar; 165(6):83844.

7 Quaderi SA, Hurst JR. The unmet global burden of COPD. Glob Health Epidemiol Genom. 2018;3:e4. 
8 Gall ET, Carter EM, Earnest CM, Stephens B. Indoor air pollution in developing countries: research and implementation needs for improvements in global public health. Am J Public Health. 2013 Apr;103(4):e67-72.

9 Alwan A, editor. Global status report on noncommunicable diseases 2010. Geneva: World Health Organization; 2011.

10 Lozano R, Naghavi M, Foreman K, Lim S, Shibuya K, Aboyans V, et al. Global and regional mortality from 235 causes of death for 20 age groups in 1990 and 2010: a systematic analysis for the Global Burden of Disease Study 2010. Lancet. 2012 Dec;380(9859):2095-128.

11 Simkovich SM, Goodman D, Roa C, Crocker ME, Gianella GE, Kirenga BJ, et al. The health and social implications of household air pollution and respiratory diseases. NPJ Prim Care Respir Med. 2019;29(1):12. Available from:https://doi.org/https://doi.org/10.1038/ s41533-019-0126-x

12 López-Campos JL, Tan W, Soriano JB. Global burden of COPD. Respirology. 2016 Jan; 21(1):14-23.

13 Soler-Cataluña JJ, Martínez-García MÁ, Román Sánchez P, Salcedo E, Navarro M, Ochando R. Severe acute exacerbations and mortality in patients with chronic obstructive pulmonary disease. Thorax. 2005 Nov;60(11): 925-31.

14 Wedzicha JA, Seemungal TA. COPD exacerbations: defining their cause and prevention. Lancet. 2007 Sep;370(9589):786-96.

15 Guarascio AJ, Ray SM, Finch CK, Self TH. The clinical and economic burden of chronic obstructive pulmonary disease in the USA. Clinicoecon Outcomes Res. 2013 Jun;5:23545. Available from: https://www.ncbi.nlm. nih.gov/pubmed/23818799

16 Hay SI; GBD 2015 Chronic Respiratory Disease Collaborators. Global, regional, and national deaths, prevalence, disability-adjusted life years, and years lived with disability for chronic obstructive pulmonary disease and asthma, 1990-2015: a systematic analysis for the Global Burden of Disease Study 2015. Lancet Respir Med. 2017 Sep;5(9):691-706.

17 Roth GA, Abate D, Abate KH, Abay SM, Abbafati C, Abbasi N, et al.; GBD 2017 Causes of Death Collaborators. Global, regional, and national age-sex-specific mortality for 282 causes of death in 195 countries and territories, 1980-2017: a systematic analysis for the Global Burden of Disease Study 2017. Lancet. 2018 Nov;392(10159):1736-88.

18 Polverino F, Celli B. The Challenge of Controlling the COPD Epidemic: unmet Needs. Am J Med. 2018 Sep;131(9S Supplement):16. Available from: http://www.sciencedirect. com/science/article/pii/S0002934318304145

19 Editorial. Air pollution: a major threat to lung health. Lancet. 2019 May;393(10183):1774.

20 Dransfield M, Stolz D, Kleinert S; Lancet COPD Commissioners. Towards eradication of chronic obstructive pulmonary disease: a Lancet Commission. Lancet. 2019 May; 393(10183):1786-8.
21 Gross NJ, Barnes PJ. New therapies for asthma and chronic obstructive pulmonary disease. Am J Respir Crit Care Med. 2017 Jan; 195(2):159-66.

22 Barnes PJ, Bonini S, Seeger W, Belvisi MG, Ward B, Holmes A. Barriers to new drug development in respiratory disease. Eur Respir J. 2015 May 1;45(5):1197-207. Available from: http://erj.ersjournals.com/content/45/5/ 1197.abstract https://doi.org/10.1183/09031936. 00007915

23 Wright JL, Cosio M, Churg A. Animal models of chronic obstructive pulmonary disease. Am J Physiol Lung Cell Mol Physiol. 2008 Jul; 295(1):L1-15. Available from: https://www. ncbi.nlm.nih.gov/pubmed/18456796 https:// doi.org/10.1152/ajplung.90200.2008

24 Jones B, Donovan C, Liu G, Gomez HM, Chimankar V, Harrison CL, et al. Animal models of COPD: what do they tell us? Respirology. 2017 Jan;22(1):21-32.

25 Stevenson CS, Birrell MA. Moving towards a new generation of animal models for asthma and COPD with improved clinical relevance. Pharmacol Ther. 2011 May;130(2):93-105. Available from: http://www.sciencedirect. com/science/article/pii/S0163725810002159

26 Fricker M, Deane A, Hansbro PM. Animal models of chronic obstructive pulmonary disease. Expert Opin Drug Discov. 2014 Jun; 9(6):629-45.

27 Roversi S, Fabbri LM, Sin DD, Hawkins NM, Agustí A. Chronic obstructive pulmonary disease and cardiac diseases. An urgent need for integrated care. Am J Respir Crit Care Med. 2016 Dec;194(11):1319-36.

28 Buist AS, McBurnie MA, Vollmer WM, Gillespie S, Burney P, Mannino DM, et al.; BOLD Collaborative Research Group. International variation in the prevalence of COPD (the BOLD Study): a population-based prevalence study. Lancet. 2007 Sep;370(9589):741-50.

29 Vogelmeier CF, Criner GJ, Martinez FJ, Anzueto A, Barnes PJ, Bourbeau J, et al. Global strategy for the diagnosis, management, and prevention of chronic obstructive lung disease 2017 report. GOLD executive summary. Am J Respir Crit Care Med. 2017 Mar; 195(5): $557-82$.

30 Woodruff PG, Barr RG, Bleecker E, Christenson SA, Couper D, Curtis JL, et al.; SPIROMICS Research Group. Clinical significance of symptoms in smokers with preserved pulmonary function. N Engl J Med. 2016 May; 374(19): 1811-21. Available from: https://www.ncbi.nlm.nih.gov/pubmed/ 27168432

31 Rodriguez-Roisin R, Han MK, Vestbo J, Wedzicha JA, Woodruff PG, Martinez FJ. Chronic Respiratory Symptoms with Normal Spirometry. A Reliable Clinical Entity? Am J Respir Crit Care Med. 2017 Jan;195(1):17-22.

32 Agusti A, Faner R, Celli B, Rodriguez-Roisin $R$. Precision medicine in COPD exacerbations. Lancet Respir Med. 2018 Sep;6(9):6579. Available from: http://www.sciencedirect. com/science/article/pii/S2213260018302960
33 Luoto JA, Elmståhl S, Wollmer P, Pihlsgård $\mathrm{M}$. Incidence of airflow limitation in subjects 65-100 years of age. Eur Respir J. 2016 Feb; 47(2):461-72. Available from: https://www. ncbi.nlm.nih.gov/pubmed/26677939

34 Johnson KM, Safari A, Tan WC, Bourbeau J, FitzGerald JM, Sadatsafavi M; Canadian Respiratory Research Network. Heterogeneity in the respiratory symptoms of patients with mild-to-moderate COPD. Int J Chron Obstruct Pulmon Dis. 2018 Dec; 13:3983-95.

35 Vogelmeier CF, Chapman KR, Miravitlles M, Roche N, Vestbo J, Thach C, et al. Exacerbation heterogeneity in COPD: subgroup analyses from the FLAME study. Int J Chron Obstruct Pulmon Dis. 2018 Apr;13:1125-34.

36 Houben-Wilke S, Augustin IM, Vercoulen $\mathrm{JH}$, van Ranst D, bij de Vaate E, Wempe JB, et al. COPD stands for complex obstructive pulmonary disease. Eur Respir Rev. 2018 Jun; 27(148):180027. Available from: http://err. ersjournals.com/content/27/148/180027.abstract

37 Mannino DM. COPD: epidemiology, prevalence, morbidity and mortality, and disease heterogeneity. Chest. 2002 May;121(5 Suppl): 121S-6S.

38 Agusti A, Calverley PM, Celli B, Coxson HO, Edwards LD, Lomas DA, et al.; Evaluation of COPD Longitudinally to Identify Predictive Surrogate Endpoints (ECLIPSE) investigators. Characterisation of COPD heterogeneity in the ECLIPSE cohort. Respir Res. 2010 Sep; 11(1):122.

39 Lopez-Campos JL, Calero C, Quintana-Gallego E. Symptom variability in COPD: a narrative review. Int $J$ Chron Obstruct Pulmon Dis. 2013;8:231-8.

40 Han MK. GOLD 2019: a new way forward. Lancet Respir Med. 2019 Jan;7(1):16-7. Available from: http://www.sciencedirect. com/science/article/pii/S2213260018304983

41 Wouters EF, Wouters BB, Augustin IM, Franssen FM. Personalized medicine and chronic obstructive pulmonary disease. Curr Opin Pulm Med. 2017 May;23(3):241-6.

42 Viniol C, Vogelmeier CF. Exacerbations of COPD. Eur Respir Rev. 2018 Mar;27(147): 170103. Available from: http://err.ersjournals.com/content/27/147/170103

43 Mannino DM, Buist AS. Global burden of COPD: risk factors, prevalence, and future trends. Lancet. 2007 Sep;370(9589):765-73.

$44 \mathrm{Ng} \mathrm{M}$, Freeman MK, Fleming TD, Robinson M, Dwyer-Lindgren L, Thomson B, et al. Smoking prevalence and cigarette consumption in 187 countries, 1980-2012. JAMA. 2014 Jan;311(2):183-92.

45 Kohansal R, Martinez-Camblor P, Agustí A, Buist AS, Mannino DM, Soriano JB. The natural history of chronic airflow obstruction revisited: an analysis of the Framingham offspring cohort. Am J Respir Crit Care Med. 2009 Jul;180(1):3-10. 
46 Wongtrakool C, Wang N, Hyde DM, Roman J, Spindel ER. Prenatal nicotine exposure alters lung function and airway geometry through $a 7$ nicotinic receptors. Am J Respir Cell Mol Biol. 2012 May;46(5):695-702. Available from: https://www.ncbi.nlm.nih. gov/pubmed/22246862

47 Stocks J, Sonnappa S. Early life influences on the development of chronic obstructive pulmonary disease. Ther Adv Respir Dis. 2013 Jun;7(3):161-73. Available from: https:// www.ncbi.nlm.nih.gov/pubmed/23439689

48 Beyer D, Mitfessel H, Gillissen A. Maternal smoking promotes chronic obstructive lung disease in the offspring as adults. Eur J Med Res. 2009 Dec 7;14(Suppl 4):27-31. Available from: https://www.ncbi.nlm.nih.gov/pubmed/ 20156720 https://doi.org/10.1186/2047783X-14-S4-27.

49 Duijts L, Reiss IK, Brusselle G, de Jongste JC. Early origins of chronic obstructive lung diseases across the life course. Eur J Epidemiol. 2014 Dec;29(12):871-85.

50 Sibille GL. Lung health in Europe, facts and figures. Lundbäck: European Lung Foundation; 2013.

51 Paulin LM, Diette GB, Blanc PD, Putcha N, Eisner MD, Kanner RE, et al.; SPIROMICS Research Group. Occupational exposures are associated with worse morbidity in patients with chronic obstructive pulmonary disease. Am J Respir Crit Care Med. 2015 Mar;191(5):557-65.

52 Zhou Y, Zou Y, Li X, Chen S, Zhao Z, He F, et al. Lung function and incidence of chronic obstructive pulmonary disease after improved cooking fuels and kitchen ventilation: a 9-year prospective cohort study. PLoS Med. 2014 Mar;11(3):e1001621.

53 Gan WQ, FitzGerald JM, Carlsten C, Sadatsafavi M, Brauer M. Associations of ambient air pollution with chronic obstructive pulmonary disease hospitalization and mortality. Am J Respir Crit Care Med. 2013 Apr;187(7):721-7.

54 King PT, MacDonald M, Bardin PG. Bacteria in COPD; their potential role and treatment. Transl Respir Med. 2013 Dec;1(1):13.

55 Hewitt R, Farne H, Ritchie A, Luke E, Johnston SL, Mallia P. The role of viral infections in exacerbations of chronic obstructive pulmonary disease and asthma. Ther Adv Respir Dis. 2016 Apr; 10(2):158-74.

56 Rennard SI, Agustí A, Vestbo J. The natural history of COPD: beyond Fletcher and Peto. BRN Rev. 2015;1(2):116-30.

57 Lange P, Celli B, Agustí A, Boje Jensen G, Divo M, Faner R, et al. Lung-Function Trajectories Leading to Chronic Obstructive Pulmonary Disease. N Engl J Med. 2015 Jul; 373(2):111-22.

58 Sakornsakolpat P, Prokopenko D, Lamontagne M, Reeve NF, Guyatt AL, Jackson VE, et al.; SpiroMeta Consortium; International COPD Genetics Consortium. Genetic landscape of chronic obstructive pulmonary disease identifies heterogeneous cell-type and phenotype associations. Nat Genet. 2019 Mar; 51(3):494-505.
59 Nussbaumer-Ochsner Y, Rabe KF. Systemic manifestations of COPD. Chest. 2011 Jan; 139(1):165-73

60 Decramer M, Janssens W. Chronic obstructive pulmonary disease and comorbidities. Lancet Respir Med. 2013 Mar;1(1):73-83.

61 Vanfleteren LE, Spruit MA, Wouters EF, Franssen FM. Management of chronic obstructive pulmonary disease beyond the lungs. Lancet Respir Med. 2016 Nov;4(11): 911-24.

62 Franssen FME, Smid DE, Deeg DJH, Huisman M, Poppelaars J, Wouters EFM, et al. The physical, mental, and social impact of COPD in a population-based sample: results from the Longitudinal Aging Study Amsterdam. NPJ Prim Care Respir Med. 2018;28(1):30. Available from: https://doi.org/https://doi. org/10.1038/s41533-018-0097-3

63 Chen W, Thomas J, Sadatsafavi M, FitzGerald JM. Risk of cardiovascular comorbidity in patients with chronic obstructive pulmonary disease: a systematic review and metaanalysis. Lancet Respir Med. 2015 Aug;3(8): 631-9.

64 Singh D, Barnes PJ, Stockley R, Valera MV, Vogelmeier C, Agusti A. Pharmacological treatment of COPD: the devil is always in the detail. Eur Respir J. 2018 Apr;51(4)1800263.

65 Jones R, Østrem A. Optimising pharmacological maintenance treatment for COPD in primary care. Prim Care Respir J. 2011 Mar; 20(1):33-45.

66 Ko FW, Wong GW. Drug Treatment for Early-Stage COPD. N Engl J Med. 2017 Sep; 377(10):988-9.

67 Scanlon PD, Connett JE, Waller LA, Altose MD, Bailey WC, Buist AS, et al.; Lung Health Study Research Group. Smoking cessation and lung function in mild-to-moderate chronic obstructive pulmonary disease. The Lung Health Study. Am J Respir Crit Care Med. 2000 Feb;161(2 Pt 1):381-90.

68 Jiménez-Ruiz CA, Andreas S, Lewis KE, Tonnesen $P$, van Schayck CP, Hajek P, et al. Statement on smoking cessation in COPD and other pulmonary diseases and in smokers with comorbidities who find it difficult to quit. Eur Respir J. 2015 Jul;46(1):61-79. Available from: http://erj.ersjournals.com/ content/46/1/61.abstract https://doi.org/10. 1183/09031936.00092614

69 Shin KC. Physical activity in chronic obstructive pulmonary disease: clinical impact and risk factors. Korean J Intern Med. 2018;33(1): 75-7. Available from: https://www.ncbi.nlm. nih.gov/pubmed/29334725

70 Spruit MA, Burtin C, De Boever P, Langer D, Vogiatzis I, Wouters EF, et al. COPD and exercise: does it make a difference? Breathe (Sheff). 2016 Jun; 12(2):e38-49. Available from: https://www.ncbi.nlm.nih.gov/pubmed/ 27408645
71 Garcia-Aymerich J, Lange $P$, Benet $M$, Schnohr P, Antó JM. Regular physical activity reduces hospital admission and mortality in chronic obstructive pulmonary disease: a population based cohort study. Thorax. 2006 Sep;61(9):772-8. Available from: https://www.ncbi.nlm.nih.gov/pubmed/ 16738033

72 Smith BM, Jensen D, Brosseau M, Benedetti A, Coxson HO, Bourbeau J. Impact of pulmonary emphysema on exercise capacity and its physiological determinants in chronic obstructive pulmonary disease. Sci Rep. 2018 Oct;8(1):15745.

73 Kopsaftis Z, Wood-Baker R, Poole P. Influenza vaccine for chronic obstructive pulmonary disease (COPD). Cochrane Database Syst Rev. 2018;6:CD002733.

74 Walters JA, Tang JN, Poole P, Wood-Baker R. Pneumococcal vaccines for preventing pneumonia in chronic obstructive pulmonary disease. Cochrane Database Syst Rev. 2017 Jan; 1:CD001390. Available from: https://www. ncbi.nlm.nih.gov/pubmed/28116747

75 Spruit MA, Singh SJ, Garvey C, ZuWallack R, Nici L, Rochester C, et al.; ATS/ERS Task Force on Pulmonary Rehabilitation. An official American Thoracic Society/European Respiratory Society statement: key concepts and advances in pulmonary rehabilitation. Am J Respir Crit Care Med. 2013 Oct; 188(8):e13-64.

76 McCarthy B, Casey D, Devane D, Murphy K, Murphy E, Lacasse Y. Pulmonary rehabilitation for chronic obstructive pulmonary disease. Cochrane Database Syst Rev. 2015; 2:CD003793.

77 Woodruff PG, Agusti A, Roche N, Singh D, Martinez FJ. Current concepts in targeting chronic obstructive pulmonary disease pharmacotherapy: making progress towards personalised management. Lancet. 2015 May;385(9979):1789-98. Available from: https://www.ncbi.nlm.nih.gov/pubmed/ 25943943

78 Wedzicha JA, Calverley PM, Seemungal TA, Hagan G, Ansari Z, Stockley RA; INSPIRE Investigators. The prevention of chronic obstructive pulmonary disease exacerbations by salmeterol/fluticasone propionate or tiotropium bromide. Am J Respir Crit Care Med. 2008 Jan;177(1):19-26.

79 Rabe KF, Fabbri LM, Israel E, Kögler H, Riemann K, Schmidt H, et al. Effect of ADRB2 polymorphisms on the efficacy of salmeterol and tiotropium in preventing COPD exacerbations: a prespecified substudy of the POETCOPD trial. Lancet Respir Med. 2014 Jan; 2(1):44-53. Available from: http://www.sciencedirect.com/science/article/pii/ S2213260013702480

80 Mapel DW, Hurley JS, Dalal AA, Blanchette $\mathrm{CM}$. The role of combination inhaled corticosteroid/long-acting $\beta$-agonist therapy in COPD management. Prim Care Respir J. 2010 Jun;19(2):93-103. 
81 Martinez FJ, Calverley PM, Goehring UM, Brose M, Fabbri LM, Rabe KF. Effect of roflumilast on exacerbations in patients with severe chronic obstructive pulmonary disease uncontrolled by combination therapy (REACT): a multicentre randomised controlled trial. Lancet. 2015 Mar;385(9971):857-66. Available from: http://www.sciencedirect. com/science/article/pii/S0140673614624107

82 Han MK, Tayob N, Murray S, Dransfield MT, Washko G, Scanlon PD, et al. Predictors of chronic obstructive pulmonary disease exacerbation reduction in response to daily azithromycin therapy. Am J Respir Crit Care Med. 2014 Jun; 189(12):1503-8. Available from: https://www.ncbi.nlm.nih.gov/pubmed/ 24779680

83 Albert RK, Connett J, Bailey WC, Casaburi R, Cooper JA Jr, Criner GJ, et al.; COPD Clinical Research Network. Azithromycin for prevention of exacerbations of COPD. N Engl J Med. 2011 Aug;365(8):689-98. Available from: https://www.ncbi.nlm.nih.gov/pubmed/ 21864166

84 Barnes PJ. Future treatments for chronic obstructive pulmonary disease and its comorbidities. Proc Am Thorac Soc. 2008 Dec;5(8): 857-64. Available from: https://www.atsjournals.org/doi/abs/10.1513/pats.200807-069TH

85 Martinez FJ, Donohue JF, Rennard SI. The future of chronic obstructive pulmonary disease treatment-difficulties of and barriers to drug development. Lancet. 2011 Sep;378(9795): 1027-37. Available from: http://www.sciencedirect.com/science/article/pii/ S0140673611610477

86 Watz H, Barnacle H, Hartley BF, Chan R. Efficacy and safety of the p38 MAPK inhibitor losmapimod for patients with chronic obstructive pulmonary disease: a randomised, double-blind, placebo-controlled trial. Lancet Respir Med. 2014 Jan;2(1):63-72. Available from: http://www.sciencedirect.com/science/ article/pii/S2213260013702005

87 Brightling CE, Bleecker ER, Panettieri RA Jr, Bafadhel M, She D, Ward CK, et al. Benralizumab for chronic obstructive pulmonary disease and sputum eosinophilia: a randomised, double-blind, placebo-controlled, phase 2a study. Lancet Respir Med. 2014 Nov; 2(11):891-901. Available from: https://www. ncbi.nlm.nih.gov/pubmed/25208464

88 Kiberstis PA. COPD risk: clues from the tree branches. Science. 2018 Feb 9;359(6376):64950. Available from: http://science.sciencemag. org/content/359/6376/649.4.abstract

89 McDonald CF. Eosinophil Biology in COPD. N Engl J Med. 2017 Oct;377(17):1680-2.

90 Pascoe SJ, Lipson DA, Locantore N, Barnacle $\mathrm{H}$, Brealey N, Mohindra R, et al. A phase III randomised controlled trial of single-dose triple therapy in COPD: the IMPACT protocol. Eur Respir J. 2016 Aug;48(2):320-30. Available from: http://erj.ersjournals.com/content/ 48/2/320.abstract https://doi.org/10.1183/ 13993003.02165-2015
91 Sliwka A, Jankowski M, Gross-Sondej I, Storman M, Nowobilski R, Bala MM. Oncedaily long-acting beta2-agonists/inhaled corticosteroids combined inhalers versus inhaled long-acting muscarinic antagonists for people with chronic obstructive pulmonary disease. Cochrane Database Syst Rev. 2018;8:CD012355.

92 Lipson DA, Barnhart F, Brealey N, Brooks J, Criner GJ, Day NC, et al.; IMPACT Investigators. Once-Daily Single-Inhaler Triple versus Dual Therapy in Patients with COPD. N Engl J Med. 2018 May;378(18):1671-80.

93 Duffy S, Weir M, Criner GJ. The complex challenge of chronic obstructive pulmonary disease. Lancet Respir Med. 2015 Dec;3(12): 917-9.

94 Divo MJ, Casanova C, Marin JM, Pinto-Plata VM, de-Torres JP, Zulueta JJ, et al.; BODE Collaborative Group. COPD comorbidities network. Eur Respir J. 2015 Sep;46(3):64050.

95 Boucherat O, Morissette MC, Provencher S, Bonnet S, Maltais F. Bridging Lung Development with Chronic Obstructive Pulmonary Disease. Relevance of Developmental Pathways in Chronic Obstructive Pulmonary Disease Pathogenesis. Am J Respir Crit Care Med. 2016 Feb;193(4):362-75.

96 Chung KF. Cytokines in chronic obstructive pulmonary disease. Eur Respir J. 2001 Jul; 18(34 suppl):50-9. Available from: http:// erj.ersjournals.com/content/18/34 suppl/50s.abstract https://doi.org/10.1183/0 9031936.01.00229701

97 Hartl D, Tirouvanziam R, Laval J, Greene CM, Habiel D, Sharma L, et al. Innate immunity of the lung: from basic mechanisms to translational medicine. J Innate Immun. 2018; 10(5-6):487-501. Available from: https://www.karger.com/DOI/10.1159/ 000487057

98 Barnes PJ. The cytokine network in asthma and chronic obstructive pulmonary disease. J Clin Invest. 2008 Nov;118(11):3546-56. Available from: https://www.ncbi.nlm.nih. gov/pubmed/18982161

99 Chatfield SM, Thieblemont N, Witko-Sarsat V. Expanding neutrophil horizons: new concepts in inflammation. J Innate Immun. 2018; 10(5-6):422-31. Available from: https://www.karger.com/DOI/10.1159/ 000493101

100 Zeiger RS, Tran TN, Butler RK, Schatz M, Li Q, Khatry DB, et al. Relationship of blood eosinophil count to exacerbations in chronic obstructive pulmonary disease. J Allergy Clin Immunol Pract. 2018 May - Jun;6(3): 944-954.e5. Available from: http://www.sciencedirect.com/science/article/pii/ S2213219817307547

101 Verhamme FM, Bracke KR, Joos GF, Brusselle GG. Transforming growth factor- $\beta$ superfamily in obstructive lung diseases. more suspects than TGF- $\beta$ alone. Am J Respir Cell Mol Biol. 2015 Jun;52(6):653-62.
102 Jang JH, Chand HS, Bruse S, Doyle-Eisele M, Royer C, McDonald J, et al. Connective tissue growth factor promotes pulmonary epithelial cell senescence and is associated with COPD severity. COPD. 2017 Apr;14(2): 228-37.

103 Ngan DA, Vickerman SV, Granville DJ, Man SF, Sin DD. The possible role of granzyme $\mathrm{B}$ in the pathogenesis of chronic obstructive pulmonary disease. Ther Adv Respir Dis. 2009 Jun;3(3):113-29.

104 Linden D, Guo-Parke H, Coyle PV, Fairley D, McAuley DF, Taggart CC, et al. Respiratory viral infection: a potential "missing link" in the pathogenesis of COPD. Eur Respir Rev. 2019 Mar;28(151): 180063. Available from: http://err.ersjournals.com/ content/28/151/180063

105 Matera MG, Calzetta L, Rogliani P, Cazzola $\mathrm{AC}$ and $\mathrm{M}$. New treatments for COPD in the elderly. Curr Pharm Des. 2014;20(38):596882. Available from: http://www.eurekaselect.com/node/120973/article

106 Mercado N, Ito K, Barnes PJ. Accelerated ageing of the lung in COPD: new concepts. Thorax. 2015 May;70(5):482-9. Available from: http://thorax.bmj.com/content/70/5/ 482.abstract https://doi.org/10.1136/thoraxjnl2014-206084

107 Paschalaki KE, Starke RD, Hu Y, Mercado N, Margariti A, Gorgoulis VG, et al. Dysfunction of endothelial progenitor cells from smokers and chronic obstructive pulmonary disease patients due to increased DNA damage and senescence. Stem Cells. 2013 Dec 31(12):2813-26. Available from: https:// www.ncbi.nlm.nih.gov/pubmed/23897750 https://doi.org/10.1002/stem.1488

108 Barnes PJ. Pulmonary diseases and ageing. In: Harris JR, Korolchuk VI, editors. Biochemistry and cell biology of ageing: part II clinical science. Singapore: Springer; 2019. p. 45-74.

109 Racanelli AC, Kikkers SA, Choi AM, Cloonan SM. Autophagy and inflammation in chronic respiratory disease. Autophagy. 2018;14(2):221-32.

110 Barnes PJ, Baker J, Donnelly LE. Cellular senescence as a mechanism and target in chronic lung diseases. Am J Respir Crit Care Med. 2019. doi: 10.1164/rccm.2018101975TR.

111 Kirkham PA, Barnes PJ. Oxidative stress in COPD. Chest. 2013 Jul;144(1):266-73.

112 Barnes PJ, Shapiro SD, Pauwels RA. Chronic obstructive pulmonary disease: molecular and cellular mechanisms. Eur Respir J. 2003 Oct;22(4):672-88.

113 Russell RE, Thorley A, Culpitt SV, Dodd S, Donnelly LE, Demattos C, et al. Alveolar macrophage-mediated elastolysis: roles of matrix metalloproteinases, cysteine, and serine proteases. Am J Physiol Lung Cell Mol Physiol. 2002 Oct;283(4):L867-73. 
114 Galbán CJ, Han MK, Boes JL, Chughtai KA, Meyer CR, Johnson TD, et al. Computed tomography-based biomarker provides unique signature for diagnosis of COPD phenotypes and disease progression. Nat Med. 2012 Nov; 18(11):1711-5.

115 McGarvey LP, John M, Anderson JA, Zvarich M, Wise RA; TORCH Clinical Endpoint Committee. Ascertainment of cause-specific mortality in COPD: operations of the TORCH Clinical Endpoint Committee. Thorax. 2007 May;62(5):411-5.

116 Barnes PJ, Celli BR. Systemic manifestations and comorbidities of COPD. Eur Respir J. 2009 May;33(5):1165-85.

117 Fermont JM, Masconi KL, Jensen MT, Ferrari R, Di Lorenzo VA, Marott JM, et al. Biomarkers and clinical outcomes in COPD: a systematic review and meta-analysis. Thorax. 2019 May;74(5):439-46. Available from: http://thorax.bmi.com/content/74/5/ 439.abstract https://doi.org/10.1136/thoraxjnl-2018-211855

118 Leptak C, Menetski JP, Wagner JA, Aubrecht J, Brady L, Brumfield M, et al. What evidence do we need for biomarker qualification? Sci Transl Med. 2017 Nov; 9(417):eaal4599. Available from: http://stm. sciencemag.org/content/9/417/eaal4599

119 Müllerova H, Maselli DJ, Locantore N, Vestbo J, Hurst JR, Wedzicha JA, et al. Hospitalized exacerbations of COPD: risk factors and outcomes in the ECLIPSE cohort. Chest. 2015 Apr;147(4):999-1007.

120 Celli BR, Locantore N, Yates J, Tal-Singer R, Miller BE, Bakke P, et al.; ECLIPSE Investigators. Inflammatory biomarkers improve clinical prediction of mortality in chronic obstructive pulmonary disease. Am J Respir Crit Care Med. 2012 May;185(10):1065-72.

121 Wedzicha JA, Seemungal TA, MacCallum PK, Paul EA, Donaldson GC, Bhowmik A, et al. Acute exacerbations of chronic obstructive pulmonary disease are accompanied by elevations of plasma fibrinogen and serum IL-6 levels. Thromb Haemost. 2000 Aug; 84(2):210-5.

122 Waschki B, Kirsten A, Holz O, Müller KC, Meyer T, Watz $\mathrm{H}$, et al. Physical activity is the strongest predictor of all-cause mortality in patients with COPD: a prospective cohort study. Chest. 2011 Aug;140(2):331-42.

123 Butler CC, Gillespie D, White P, Bates J, Lowe R, Thomas-Jones E, et al. C-reactive protein testing to guide antibiotic prescribing for COPD exacerbations. N Engl J Med. 2019 Jul;381(2):111-20.

124 Hurst JR, Vestbo J, Anzueto A, Locantore N, Müllerova H, Tal-Singer R, et al.; Evaluation of COPD Longitudinally to Identify Predictive Surrogate Endpoints (ECLIPSE) Investigators. Susceptibility to exacerbation in chronic obstructive pulmonary disease. $\mathrm{N}$ Engl J Med. 2010 Sep;363(12):1128-38.
125 Grolimund E, Kutz A, Marlowe RJ, Vögeli A, Alan M, Christ-Crain M, et al.; ProHOSP Study Group. Long-term prognosis in COPD exacerbation: role of biomarkers, clinical variables and exacerbation type. COPD. 2015 Jun;12(3):295-305.

126 Chen YW, Leung JM, Sin DD. A Systematic Review of Diagnostic Biomarkers of COPD Exacerbation. PLoS One. 2016 Jul; 11(7):e0158843-0158843. Available from: https://www.ncbi.nlm.nih.gov/pubmed/ 27434033

127 Zemans RL, Jacobson S, Keene J, Kechris K, Miller BE, Tal-Singer R, et al. Multiple biomarkers predict disease severity, progression and mortality in COPD. Respir Res. 2017 Jun;18(1):117.

128 Pouwels SD, Klont F, Kwiatkowski MD, Wiersma VR, Horvatovich P, Bischoff R, et al. Cigarette smoking acutely decreases the serum levels of the COPD biomarker sRAGE. Eur Respir J. 2018 Sep;52 suppl 62:OA3812. Available from: http://erj.ersjournals.com/ content/52/suppl_62/OA3812

129 Miller BE, Tal-Singer R, Rennard SI, Furtwaengler A, Leidy $\mathrm{N}$, Lowings $\mathrm{M}$, et al.; Perspective of the Chronic Obstructive Pulmonary Disease Biomarker Qualification Consortium. Plasma fibrinogen qualification as a drug development tool in chronic obstructive pulmonary disease. Am J Respir Crit Care Med. 2016 Mar; 193(6):607-13.

130 Sambamurthy N, Leme AS, Oury TD, Shapiro SD. The receptor for advanced glycation end products (RAGE) contributes to the progression of emphysema in mice. PLoS One. 2015 Mar;10(3):e0118979.

131 Wilberding JA, Ploplis VA, McLennan L, Liang Z, Cornelissen I, Feldman M, et al. Development of pulmonary fibrosis in fibrinogen-deficient mice. Ann N Y Acad Sci. 2001; 936(1):542-8.

132 Tewari AK, Popova-Butler A, El-Mahdy MA, Zweier JL. Identification of differentially expressed proteins in blood plasma of control and cigarette smoke-exposed mice by 2 -D DIGE/MS. Proteomics. 2011 May; 11(10):2051-62.

133 Hattori N, Degen JL, Sisson TH, Liu H, Moore BB, Pandrangi RG, et al. Bleomycininduced pulmonary fibrosis in fibrinogennull mice. J Clin Invest. 2000 Dec;106(11): 1341-50.

134 Wilde M, Cordell R, Richardson M, Ibrahim W, Zhao B, Salman D, et al. Optimising the discovery of breath-based biomarkers for phenotyping acute exacerbations of asthma and COPD. Am J Respir Crit Care Med. 2019;199:A1292.

135 Stockley RA. Biomarkers in chronic obstructive pulmonary disease: confusing or useful? Int J Chron Obstruct Pulmon Dis. 2014 Feb;9:163-77. Available from: https:// www.ncbi.nlm.nih.gov/pubmed/24532968
136 Mertens TC, Karmouty-Quintana H, Taube C, Hiemstra PS. Use of airway epithelial cell culture to unravel the pathogenesis and study treatment in obstructive airway diseases. Pulm Pharmacol Ther. 2017 Aug;45: 101-13. Available from: http://www.sciencedirect.com/science/article/pii/ S1094553917300639

137 Amatngalim GD, Schrumpf JA, Henic A, Dronkers E, Verhoosel RM, Ordonez SR, et al. Antibacterial defense of human airway epithelial cells from chronic obstructive pulmonary disease patients induced by acute exposure to nontypeable Haemophilus influenzae: modulation by cigarette smoke. J Innate Immun. 2017 Jul;9(4):359-74. Available from: https://www.ncbi.nlm.nih.gov/ pubmed $/ 28171878$

138 Schamberger AC, Staab-Weijnitz CA, MiseRacek N, Eickelberg O. Cigarette smoke alters primary human bronchial epithelial cell differentiation at the air-liquid interface. Sci Rep. 2015 Feb;5(1):8163.

139 Franks TJ, Colby TV, Travis WD, Tuder RM, Reynolds HY, Brody AR, et al. Resident cellular components of the human lung: current knowledge and goals for research on cell phenotyping and function. Proc Am Thorac Soc. 2008 Sep;5(7):763-6. Available from: https://www.atsjournals.org/doi/abs/ 10.1513/pats.200803-025HR

140 Garcia-Canton C, Minet E, Anadon A, Meredith C. Metabolic characterization of cell systems used in in vitro toxicology testing: lung cell system BEAS-2B as a working example. Toxicol Vitr. 2013;27(6):1719-27. Available from: http://www.sciencedirect. c o m / s cie n ce / a r t i cle/pi i / S0887233313001239

141 Strong P, Ito K, Murray J, Rapeport G. Current approaches to the discovery of novel inhaled medicines. Drug Discov Today. 2018 Oct;23(10):1705-17. Available from: http:// www.sciencedirect.com/science/article/pii/ S1359644617305822

142 Adamson J, Haswell LE, Phillips G, Gaça MD. In vitro models of chronic obstructive pulmonary disease (COPD). IntechOpen. 2011. doi: $10.5772 / 18247$.

143 Krimmer DI, Oliver BG. What can in vitro models of COPD tell us? Pulm Pharmacol Ther. 2011 Oct;24(5):471-7. [cited 2019 Jun 29] Available from: https://www.sciencedirect.com/science/article/pi / S1094553910001446?via\%3Dihub

144 Huang S, Wiszniewski L, Constant S, Roggen E. Potential of in vitro reconstituted 3D human airway epithelia (MucilAirTM) to assess respiratory sensitizers. Toxicol Vitr. 2013;27(3):1151-6. Available from: http:// www.sciencedirect.com/science/article/pii/ S088723331200286X 
145 Marrazzo P, Maccari S, Taddei A, Bevan L, Telford J, Soriani M, et al. 3D Reconstruction of the Human Airway Mucosa In Vitro as an Experimental Model to Study NTHi Infections. PLoS One. 2016 Apr; 11(4):e0153985-0153985. Available from: https://www.ncbi.nlm.nih.gov/pubmed/ 27101006

146 Castellani S, Di Gioia S, di Toma L, Conese M. Human cellular models for the investigation of lung inflammation and mucus production in cystic fibrosis. Anal Cell Pathol. 2018 Nov;2018:3839803. Available from: https://www.ncbi.nlm.nih.gov/pubmed/ 30581723

147 Zscheppang K, Berg J, Hedtrich S, Verheyen L, Wagner DE, Suttorp N, et al. Human pulmonary $3 \mathrm{D}$ models for translational research. Biotechnol J. 2018 Jan;13(1): 1700341.

148 Bauer C, Golgi J, Lambert K, Cheng D, Giron $\mathrm{M}$, Allard J, et al. Precision cut lung slices: A novel method for examining mechanisms underlying respiratory diseases. Eur Respir J. 2013 Sep;42 Suppl 57:669. Available from: http://erj.ersjournals.com/content/42/Suppl_57/P669

149 Tronde A, Nordén B, Jeppsson AB, Brunmark P, Nilsson E, Lennernäs H, et al. Drug absorption from the isolated perfused rat lung - correlations with drug physicochemical properties and epithelial permeability. J Drug Target. 2003 Jan;11(1):61-74.

150 Gnadt M, Trammer B, Freiwald M, Kardziev B, Bayliss MK, Edwards CD, et al. Methacholine delays pulmonary absorption of inhaled $\beta(2)$-agonists due to competition for organic cation/carnitine transporters. Pulm Pharmacol Ther. 2012 Feb;25(1):124-34. Available from: http://www.sciencedirect. c o m / s cie nce/article/pi i/ S1094553912000028

151 Tan Q, Choi KM, Sicard D, Tschumperlin DJ. Human airway organoid engineering as a step toward lung regeneration and disease modeling. Biomaterials. 2017 Jan;113:11832. Available from: https://www.ncbi.nlm. nih.gov/pubmed/27815996

152 Leeman KT, Pessina P, Lee J, Kim CF. Mesenchymal stem cells increase alveolar differentiation in lung progenitor organoid cultures. Sci Rep. 2019;9(1):6479.

153 Sachs N, Papaspyropoulos A, Zomer-van Ommen DD, Heo I, Böttinger L, Klay D, et al. Long-term expanding human airway organoids for disease modeling. EMBO J. 2019 Feb;38(4):e100300. Available from: https:// www.ncbi.nlm.nih.gov/pubmed/30643021 https://doi.org/10.15252/embj.2018100300

154 Benam KH, Villenave R, Lucchesi C, Hubeau C, Varone A, Ferrante TC, et al. Small airway-on-a-chip: a novel microphysiological system to study human lung inflammation in vitro. Eur J Immunol. 2016; 48(60):OA4542. doi: 10.1183/13993003. congress-2016.OA4542.
155 Benam KH, Mazur M, Choe Y, Ferrante TC, Novak R, Ingber DE. Human lung small airway-on-a-chip protocol. In: Koledova Z, editor. 3D cell culture: methods and protocols. New York: Springer; 2017. pp. 345-65.

156 Mittal R, Woo FW, Castro CS, Cohen MA, Karanxha J, Mittal J, et al. Organ-on-chip models: implications in drug discovery and clinical applications. J Cell Physiol. 2019 Jun; 234(6):8352-80.

157 Wang S, Zhu R, Li H, Li J, Han Q, Zhao RC. Mesenchymal stem cells and immune disorders: from basic science to clinical transition. Front Med. 2019 Apr;13(2):138-51.

$158 \mathrm{Hu}$, Ogle BM, Cheng K. Body builder: from synthetic cells to engineered tissues. Curr Opin Cell Biol. 2018 Oct;54:37-42. Available from: http://www.sciencedirect.com/science/article/pii/S0955067418300292

159 Barré-Sinoussi F, Montagutelli X. Animal models are essential to biological research: issues and perspectives. Futur Sci OA. 2015 Nov; 1(4):FSO63-FSO63. Available from: https://www.ncbi.nlm.nih.gov/pubmed/ 28031915 https://doi.org/10.4155/fso.15.63

160 Reczyńska K, Tharkar P, Kim SY, Wang Y, Pamuła E, Chan HK, et al. Animal models of smoke inhalation injury and related acute and chronic lung diseases. Adv Drug Deliv Rev. 2018 Jan;123:107-34. Available from: http://www.sciencedirect.com/science/article/pii/S0169409X17302193

161 Vlahos R, Bozinovski S, Gualano RC, Ernst $\mathrm{M}$, Anderson GP. Modelling COPD in mice. Pulm Pharmacol Ther. 2006;19(1):12-7. Available from: http://www.sciencedirect. c o m/s cience/article/pi i/ S1094553905000386

162 Wright JL, Churg A. Animal models of cigarette smoke-induced chronic obstructive pulmonary disease. Expert Rev Respir Med. 2010 Dec;4(6):723-34.

163 Coggins CR. An updated review of inhalation studies with cigarette smoke in laboratory animals. Int J Toxicol. 2007 Jul-Aug; 26(4):331-8.

164 Lucey EC, Goldstein RH, Stone PJ, Snider GL. Remodeling of alveolar walls after elastase treatment of hamsters. Results of elastin and collagen mRNA in situ hybridization. Am J Respir Crit Care Med. 1998 Aug; 158(2):555-64.

165 Snider GL, Lucey EC, Stone PJ. Animal models of emphysema. Am Rev Respir Dis. 1986 Jan;133(1):149-69.

166 Wright JL, Churg A. Cigarette smoke causes physiologic and morphologic changes of emphysema in the guinea pig. Am Rev Respir Dis. 1990 Dec;142(6 Pt 1):1422-8.

167 Churg A, Cosio M, Wright JL. Mechanisms of cigarette smoke-induced COPD: insights from animal models. Am J Physiol Lung Cell Mol Physiol. 2008 Apr;294(4):L612-31.
168 Canning BJ, Wright JL. Animal models of asthma and chronic obstructive pulmonary disease. Pulm Pharmacol Ther. 2008 Oct; 21(5):695. Available from: http://www.sciencedirect.com/science/article/pii/ S1094553908000503

169 Karlinsky JB, Snider GL. Animal models of emphysema. Am Rev Respir Dis. 1978 Jun; 117(6):1109-33.

170 Laurell CB, Eriksson S. The electrophoretic a1-globulin pattern of serum in $\alpha 1$ antitrypsin deficiency. Scand J Clin Lab Invest. 1963;15:132-40.

171 Gross P, Pfitzer EA, Tolker E, Babyak MA, Kaschak M. Experimental emphysema: its production with papain in normal and silicotic rats. Arch Environ Health. 1965 Jul; 11(1):50-8.

172 Petrache I, Fijalkowska I, Medler TR, Skirball J, Cruz P, Zhen L, et al. $\alpha$ - 1 antitrypsin inhibits caspase- 3 activity, preventing lung endothelial cell apoptosis. Am J Pathol. 2006 Oct;169(4):1155-66.

173 Busch RH, Lauhala KE, Loscutoff SM, McDonald KE. Experimental pulmonary emphysema induced in the rat by intratracheally administered elastase: morphogenesis. Environ Res. 1984 Apr;33(2):497-513.

174 Hayes JA, Korthy A, Snider GL. The pathology of elastase-induced panacinar emphysema in hamsters. J Pathol. 1975 Sep;117(1): $1-14$.

175 Fehrenbach H. Animal models of pulmonary emphysema: a stereologist's perspective. Eur Respir Rev. 2006 Dec;15(101):13647. Available from: http://err.ersjournals. com/content/15/101/136.abstract https:// doi.org/10.1183/09059180.00010104

176 Groneberg DA, Chung KF. Models of chronic obstructive pulmonary disease. Respir Res. 2004 Nov;5(1):18.

177 Rydell-Törmänen K, Johnson JR. The applicability of mouse models to the study of human disease. Methods Mol Biol. 2019;1940: 3-22.

$178 \mathrm{Gu}$ BH, Sprouse ML, Madison MC, Hong MJ, Yuan X, Tung HY, et al. A novel animal model of emphysema induced by anti-elastin autoimmunity. J Immunol. 2019 Jul; 203(2):349-59. Available from: http://www. jimmunol.org/content/203/2/349.abstract

179 Hardin M, Silverman EK. Chronic obstructive pulmonary disease genetics: a review of the past and a look into the future. Chronic Obstr Pulm Dis. 2014 May;1(1):33-46. Available from: https://www.ncbi.nlm.nih. gov/pubmed/28848809 https://doi.org/10. 15326/jcopdf.1.1.2014.0120

180 Silverman EK. Progress in chronic obstructive pulmonary disease genetics. Proc Am Thorac Soc. 2006 Jul;3(5):405-8.

181 Shapiro SD. Animal models for COPD. Chest. 2000 May;117(5 Suppl 1):223S-7S.

182 Hokuto I, Perl AK, Whitsett JA. Prenatal, but not postnatal, inhibition of fibroblast growth factor receptor signaling causes emphysema. J Biol Chem. 2003 Jan;278(1):415-21. 
183 Perl AK, Tichelaar JW, Whitsett JA. Conditional gene expression in the respiratory epithelium of the mouse. Transgenic Res. 2002 Feb;11(1):21-9.

184 Fujita M, Nakanishi Y. The pathogenesis of COPD: lessons learned from in vivo animal models. Med Sci Monit. 2007 Feb; 13(2):RA19-24.

185 Sakazaki Y, Hoshino T, Takei S, Sawada M, Oda $\mathrm{H}$, Takenaka $\mathrm{S}$, et al. Overexpression of chitinase 3 -like $1 /$ YKL-40 in lung-specific IL-18-transgenic mice, smokers and COPD. PLoS One. 2011;6(9):e24177.

186 D’Armiento J, Dalal SS, Okada Y, Berg RA, Chada K. Collagenase expression in the lungs of transgenic mice causes pulmonary emphysema. Cell. 1992 Dec;71(6):955-61. Available from: http://www.sciencedirect. com/science/article/pii/0092867492903910

187 Shapiro SD. Transgenic and gene-targeted mice as models for chronic obstructive pulmonary disease. Eur Respir J. 2007 Feb; 29(2):375-8. Available from: http://erj.ersjournals.com/content/29/2/375.abstract

188 Hunninghake GM, Cho MH, Tesfaigzi Y, Soto-Quiros ME, Avila L, Lasky-Su J, et al. MMP12, lung function, and COPD in highrisk populations. N Engl J Med. 2009 Dec; 361(27):2599-608.

189 Houghton AM, Quintero PA, Perkins DL, Kobayashi DK, Kelley DG, Marconcini LA, et al. Elastin fragments drive disease progression in a murine model of emphysema. J Clin Invest. 2006 Mar;116(3):753-9.

190 Hautamaki RD, Kobayashi DK, Senior RM, Shapiro SD. Requirement for macrophage elastase for cigarette smoke-induced emphysema in mice. Science. 1997;277(5334): 2002-4. https://doi.org/10.1126/science.277. 5334.2002

191 Woodruff PG, Koth LL, Yang YH, Rodriguez MW, Favoreto S, Dolganov GM, et al. A distinctive alveolar macrophage activation state induced by cigarette smoking. Am J Respir Crit Care Med. 2005 Dec;172(11): 1383-92.

192 Leberl M, Kratzer A, Taraseviciene-Stewart L. Tobacco smoke induced COPD/emphysema in the animal model - are we all on the same page? Front Physiol. 2013 May;4:91. Available from: https://www.ncbi.nlm.nih. gov/pubmed/23720629

193 Ofulue AF, Ko M. Effects of depletion of neutrophils or macrophages on development of cigarette smoke-induced emphysema. Am J Physiol. 1999 Jul;277(1):L97-105.

194 Kratzer A, Salys J, Nold-Petry C, Cool C, Zamora M, Bowler R, et al. Role of IL-18 in second-hand smoke-induced emphysema. Am J Respir Cell Mol Biol. 2013 Jun;48(6): 725-32.

195 Williams K, Roman J. Studying human respiratory disease in animals-role of induced and naturally occurring models. J Pathol. 2016 Jan;238(2):220-32.
196 Hasday JD, Bascom R, Costa JJ, Fitzgerald T, Dubin W. Bacterial endotoxin is an active component of cigarette smoke. Chest. 1999 Mar;115(3):829-35.

197 Rylander R. Endotoxin and occupational airway disease. Curr Opin Allergy Clin Immunol. 2006 Feb;6(1):62-6.

198 Patel IS, Seemungal TA, Wilks M, LloydOwen SJ, Donaldson GC, Wedzicha JA. Relationship between bacterial colonisation and the frequency, character, and severity of COPD exacerbations. Thorax. 2002 Sep; 57(9):759-64.

199 Wilkinson TM, Hurst JR, Perera WR, Wilks M, Donaldson GC, Wedzicha JA. Effect of interactions between lower airway bacterial and rhinoviral infection in exacerbations of COPD. Chest. 2006 Feb;129(2):317-24.

200 Spond J, Case N, Chapman RW, Crawley Y, Egan RW, Fine J, et al. Inhibition of experimental acute pulmonary inflammation by pirfenidone. Pulm Pharmacol Ther. 2003; 16(4):207-14

201 Toward TJ, Broadley KJ. Early and late bronchoconstrictions, airway hyper-reactivity, leucocyte influx and lung histamine and nitric oxide after inhaled antigen: effects of dexamethasone and rolipram. Clin Exp Allergy. 2004 Jan;34(1):91-102.

202 Toward TJ, Broadley KJ. Chronic lipopolysaccharide exposure on airway function, cell infiltration, and nitric oxide generation in conscious guinea pigs: effect of rolipram and dexamethasone. J Pharmacol Exp Ther. 2001 Jul;298(1):298-306.

203 Vernooy JH, Dentener MA, van Suylen RJ, Buurman WA, Wouters EF. Long-term intratracheal lipopolysaccharide exposure in mice results in chronic lung inflammation and persistent pathology. Am J Respir Cell Mol Biol. 2002 Jan;26(1):152-9.

204 Vernooy JH, Dentener MA, van Suylen RJ, Buurman WA, Wouters EF. Intratracheal instillation of lipopolysaccharide in mice induces apoptosis in bronchial epithelial cells: no role for tumor necrosis factor- $\alpha$ and infiltrating neutrophils. Am J Respir Cell Mol Biol. 2001 May;24(5):569-76.

205 Nagai H, Tsuji F, Shimazawa T, Goto S, Yoshitake K, Koda A. Participation of collagenase and elastase in LPS-induced airway hyperresponsiveness in guinea pigs. Inflammation. 1991 Aug;15(4):317-30.

206 Toward TJ, Broadley KJ. Goblet cell hyperplasia, airway function, and leukocyte infiltration after chronic lipopolysaccharide exposure in conscious Guinea pigs: effects of rolipram and dexamethasone. J Pharmacol Exp Ther. 2002 Aug;302(2):814-21.

207 Brass DM, Hollingsworth JW, Cinque M, Li Z, Potts E, Toloza E, et al. Chronic LPS inhalation causes emphysema-like changes in mouse lung that are associated with apoptosis. Am J Respir Cell Mol Biol. 2008 Nov; 39(5):584-90.
208 Baarsma HA, Bos S, Meurs H, Visser KH, Smit M, Schols AM, et al. Pharmacological inhibition of GSK-3 in a guinea pig model of LPS-induced pulmonary inflammation: I. Effects on lung remodeling and pathology. Respir Res. 2013 Oct;14(1):113.

209 Pera T, Zuidhof A, Valadas J, Smit M, Schoemaker RG, Gosens R, et al. Tiotropium inhibits pulmonary inflammation and remodelling in a guinea pig model of COPD. Eur Respir J. 2011 Oct;38(4):789-96.

210 Sohn SH, Jang H, Kim Y, Jang YP, Cho SH, Jung H, et al. The effects of Gamijinhae-tang on elastase/lipopolysaccharide-induced lung inflammation in an animal model of acute lung injury. BMC Complement Altern Med. 2013 Jul;13(1):176.

211 Lee SY, Cho JH, Cho SS, Bae CS, Kim GY, Park DH. Establishment of a chronic obstructive pulmonary disease mouse model based on the elapsed time after LPS intranasal instillation. Lab Anim Res. 2018 Mar 34(1):1-10. Available from: https://www. ncbi.nlm.nih.gov/pubmed/29628971 https://doi.org/10.5625/lar.2018.34.1.1

212 Ghorani V, Boskabady MH, Khazdair MR, Kianmeher M. Experimental animal models for COPD: a methodological review. Tob Induc Dis. 2017 May;15(1):25. Available from: https://www.ncbi.nlm.nih.gov/pubmed/ 28469539

213 Sethi S, Evans N, Grant BJ, Murphy TF. New strains of bacteria and exacerbations of chronic obstructive pulmonary disease. $\mathrm{N}$ Engl J Med. 2002 Aug;347(7):465-71.

214 Sethi S, Murphy TF. Infection in the pathogenesis and course of chronic obstructive pulmonary disease. N Engl J Med. 2008 Nov; 359(22):2355-65.

215 Ganesan S, Faris AN, Comstock AT, Sonstein J, Curtis JL, Sajjan US. Elastase/LPSexposed mice exhibit impaired innate immune responses to bacterial challenge: role of scavenger receptor A. Am J Pathol. 2012 Jan;180(1):61-72.

216 Sajjan U, Ganesan S, Comstock AT, Shim J, Wang Q, Nagarkar DR, et al. Elastase- and LPS-exposed mice display altered responses to rhinovirus infection. Am J Physiol Lung Cell Mol Physiol. 2009 Nov;297(5):L931-44

217 Kobayashi S, Fujinawa R, Ota F, Kobayashi $\mathrm{S}$, Angata T, Ueno M, et al. A single dose of lipopolysaccharide into mice with emphysema mimics human chronic obstructive pulmonary disease exacerbation as assessed by micro-computed tomography. Am J Respir Cell Mol Biol. 2013 Dec;49(6):971-7.

218 Sleijfer S. Bleomycin-induced pneumonitis. Chest. 2001 Aug;120(2):617-24.

219 Walkin L, Herrick SE, Summers A, Brenchley PE, Hoff CM, Korstanje R, et al. The role of mouse strain differences in the susceptibility to fibrosis: a systematic review. Fibrogenesis Tissue Repair. 2013 Sep;6(1):18 Available from: https://www.ncbi.nlm.nih. gov/pubmed/24294831 
220 Tashiro J, Rubio GA, Limper AH, Williams K, Elliot SJ, Ninou I, et al. Exploring animal models that resemble idiopathic pulmonary fibrosis. Front Med. 2017 Jul;4:118.

221 Naik PK, Bozyk PD, Bentley JK, Popova AP, Birch CM, Wilke CA, et al.; COMET Investigators. Periostin promotes fibrosis and predicts progression in patients with idiopathic pulmonary fibrosis. Am J Physiol Lung Cell Mol Physiol. 2012 Dec; 303(12):L1046-56.

222 B Moore B, Lawson WE, Oury TD, Sisson TH, Raghavendran K, Hogaboam CM; B. Moore B. Animal models of fibrotic lung disease. Am J Respir Cell Mol Biol. 2013 Aug;49(2):167-79.

223 Rydell-Törmänen K, Andréasson K, Hesselstrand R, Risteli J, Heinegård D, Saxne T, et al. Extracellular matrix alterations and acute inflammation; developing in parallel during early induction of pulmonary fibrosis. Lab Invest. 2012 Jun;92(6):917-25.

224 Peters LL, Robledo RF, Bult CJ, Churchill GA, Paigen BJ, Svenson KL. The mouse as a model for human biology: a resource guide for complex trait analysis. Nat Rev Genet. 2007 Jan;8(1):58-69.

225 Yue F, Cheng Y, Breschi A, Vierstra J, Wu W, Ryba T, et al.; Mouse ENCODE Consortium. A comparative encyclopedia of DNA elements in the mouse genome. Nature. 2014 Nov;515(7527):355-64.

226 Mahadeva R, Shapiro SD. Chronic obstructive pulmonary disease * 3 : experimental animal models of pulmonary emphysema. Thorax. 2002 Oct;57(10):908-14. Available from: https://www.ncbi.nlm.nih.gov/pubmed/ 12324680

227 Flint J, Eskin E. Genome-wide association studies in mice. Nat Rev Genet. 2012 Nov; 13(11):807-17.

228 Rinaldi M, Maes K, De Vleeschauwer S, Thomas D, Verbeken EK, Decramer M, et al. Long-term nose-only cigarette smoke exposure induces emphysema and mild skeletal muscle dysfunction in mice. Dis Model Mech. 2012 May;5(3):333-41. Available from: http:// dmm.biologists.org/content/5/3/333.abstract https://doi.org/10.1242/dmm.008508

229 Bartalesi B, Cavarra E, Fineschi S, Lucattelli M, Lunghi B, Martorana PA, et al. Different lung responses to cigarette smoke in two strains of mice sensitive to oxidants. Eur Respir J. 2005 Jan;25(1):15-22. Available from: http://erj.ersjournals.com/content/25/ 1/15.abstract

230 Engle ML, Monk JN, Jania CM, Martin JR, Gomez JC, Dang H, et al. Dynamic changes in lung responses after single and repeated exposures to cigarette smoke in mice. PLoS One. 2019 Feb;14(2):e0212866.

231 Vlahos R, Bozinovski S. Preclinical murine models of chronic obstructive pulmonary disease. Eur J Pharmacol. 2015 Jul;759:265-71. Available from: http://www.sciencedirect. com/science/article/pii/S0014299915002447
232 Vlahos R, Bozinovski S. Recent advances in pre-clinical mouse models of COPD. Clin Sci. 2014 Feb;126(4):253-65. Available from: https://www.ncbi.nlm.nih.gov/pubmed/ 24144354

233 Kumar RK, Herbert C, Foster PS. Mouse models of acute exacerbations of allergic asthma. Respirology. 2016 Jul;21(5):842-9.

234 Harkema JR, Morgan KT. Normal morphology of the nasal passages in laboratory rodents. In: Jones TC, Dungworth DL, Mohr $\mathrm{U}$, editors. Respiratory system monographs on pathology of laboratory animals. Berlin, Heidelberg: Springer; 1996. p. 3-17.

235 Matute-Bello G, Frevert CW, Martin TR Animal models of acute lung injury. Am J Physiol Lung Cell Mol Physiol. 2008 Sep; 295(3):L379-99. Available from: https:// www.ncbi.nlm.nih.gov/pubmed/18621912 https://doi.org/10.1152/ajplung.00010.2008

236 March TH, Barr EB, Finch GL, Hahn FF, Hobbs $\mathrm{CH}$, Ménache MG, et al. Cigarette smoke exposure produces more evidence of emphysema in B6C3F1 mice than in F344 rats. Toxicol Sci. 1999 Oct;51(2):289-99.

237 Watanabe TK, Bihoreau MT, McCarthy LC, Kiguwa SL, Hishigaki H, Tsuji A, et al. A radiation hybrid map of the rat genome containing 5,255 markers. Nat Genet. 1999 May; 22(1):27-36.

238 Tuggle KL, Birket SE, Cui X, Hong J, Warren J, Reid L, et al. Characterization of defects in ion transport and tissue development in cystic fibrosis transmembrane conductance regulator (CFTR)-knockout rats. PLoS One. 2014 Mar;9(3):e91253.

239 Iannaccone PM, Jacob HJ. Rats! Dis Model Mech. 2009 May-Jun;2(5-6):206-10. Available from: https://www.ncbi.nlm.nih.gov/ pubmed/19407324

240 Fröhlich E, Salar-Behzadi S. Toxicological assessment of inhaled nanoparticles: role of in vivo, ex vivo, in vitro, and in silico studies. Int J Mol Sci. 2014 Mar;15(3):4795-822.

241 Hofmann W, Koblinger L, Martonen TB. Structural differences between human and rat lungs: implications for Monte Carlo modeling of aerosol deposition. Health Phys. 1989;57(suppl 1):41-6.

242 Chen X, Liu Q, Wang D, Feng S, Zhao Y, Shi $\mathrm{Y}$, et al. Protective effects of hydrogen-rich saline on rats with smoke inhalation injury. Oxid Med Cell Longev. 2015;2015. https:// doi.org/10.1155/2015/106836.

243 Cambau E, Drancourt M. Steps towards the discovery of Mycobacterium tuberculosis by Robert Koch, 1882. Clin Microbiol Infect. 2014 Mar;20(3):196-201

244 Padilla-Carlin DJ, McMurray DN, Hickey AJ. The guinea pig as a model of infectious diseases. Comp Med. 2008 Aug;58(4):32440.

245 Canning BJ, Chou Y. Using guinea pigs in studies relevant to asthma and COPD. Pulm Pharmacol Ther. 2008 Oct;21(5):702-20. Available from: http://www.sciencedirect. com/science/article/pii/S1094553908000096
246 Ricciardolo FLM, Nijkamp F, De Rose V, Folkerts G. The guinea pig as an animal model for asthma. Curr Drug Targets. 2008 9(6):452-65. Available from: http://www. eurekaselect.com/node/67088/article

247 Ramírez-Ramírez E, Torres-Ramírez A, Alquicira-Mireles J, Cañavera-Constantino A, Segura-Medina P, Montaño-Ramírez M, et al. Characteristic plethysmographic findings in a guinea pig model of COPD. Exp Lung Res. 2017 Mar;43(2):57-65.

248 Yarto-Jaramillo E. Respiratory system anatomy, physiology, and disease: guinea pigs and chinchillas. Vet Clin North Am Exot Anim Pract. 2011 May;14(2):339-55.

249 Schreider JP, Hutchens JO. Morphology of the guinea pig respiratory tract. Anat Rec. 1980 Mar;196(3):313-21.

250 Burns AR, Hosford SP, Dunn LA, Walker DC, Hogg JC. Respiratory epithelial permeability after cigarette smoke exposure in guinea pigs. J Appl Physiol (1985). 1989 May;66(5):2109-16.

251 Fryer AD, Jacoby DB. Parainfluenza virus infection damages inhibitory M2 muscarinic receptors on pulmonary parasympathetic nerves in the guinea-pig. $\mathrm{Br} \mathrm{J}$ Pharmacol. 1991 Jan;102(1):267-71.

252 McMurray DN. Guinea pig model of tuberculosis. In: Bloom BR, editor. Tuberculosis. Washington: ASM Press; 1994. p. 135-47.

253 Manning PJ, Wagner JE, Harkness JE. Biology and diseases of guinea pigs. In: Fox JG, Cohen BJ, Loew FM, editors. Laboratory Animal Medicine. London: Academic Press; 1984.

254 Nambiar MP, Gordon RK, Moran TS, Richards SM, Sciuto AM. A simple method for accurate endotracheal placement of an intubation tube in Guinea pigs to assess lung injury following chemical exposure. Toxicol Mech Methods. 2007;17(7):385-92.

255 Brewer NR, Cruise LJ. The respiratory system of the guinea pig: emphasis on species differences. Contemp Top Lab Anim Sci. 1997 Jan;36(1):100-8.

256 Warner BM, Safronetz D, Kobinger GP. Syrian hamsters as a small animal model for emerging infectious diseases: advances in immunologic methods. In: Rezza G, Ippolito $\mathrm{G}$, editors. Emerging and re-emerging viral infections. Berlin: Springer; 2016. p. 87-101.

257 Wold WS, Tollefson AE, Ying B, Spencer JF, Toth K. Drug development against human adenoviruses and its advancement by Syrian hamster models. FEMS Microbiol Rev. 2019 Jul;43(4):380-8.

258 Germann PG, Ernst H. S17: The Syrian golden hamster: Recent application in drug development and registration. Exp Toxicol Pathol. 2009;61(3):264. Available from: http://www.sciencedirect.com/science/article/pii/S0940299309000244

259 Dörger M, Jesch NK, Rieder G, Hirvonen MR, Savolainen K, Krombach F, et al. Species differences in $\mathrm{NO}$ formation by rat and hamster alveolar macrophages in vitro]. Am J Respir Cell Mol Biol. 1997 Apr;16(4):413-20. 
260 Bernfeld P, Homburger F, Soto E, Pai KJ. Cigarette smoke inhalation studies in inbred Syrian golden hamsters. J Natl Cancer Inst. 1979 Sep;63(3):675-89.

261 McCusker K, Hoidal J. Selective increase of antioxidant enzyme activity in the alveolar macrophages from cigarette smokers and smoke-exposed hamsters. Am Rev Respir Dis. 1990 Mar;141(3):678-82.

262 Hoidal JR, Niewoehner DE. Cigarette smoke inhalation potentiates elastase-induced emphysema in hamsters. Am Rev Respir Dis. 1983 Apr;127(4):478-81.

263 Cantor J, Ochoa A, Ma S, Liu X, Turino G. Free Desmosine is a Sensitive Marker of Smoke-Induced Emphysema. Lung. 2018 Dec;196(6):659-63.

264 Nemmar A, Nemery B, Hoet PH, Vermylen J, Hoylaerts MF. Pulmonary inflammation and thrombogenicity caused by diesel particles in hamsters: role of histamine. Am J Respir Crit Care Med. 2003 Dec;168(11): 1366-72.

265 Heinrich U, Muhle H, Takenaka S, Ernst H, Fuhst R, Mohr U, et al. Chronic effects on the respiratory tract of hamsters, mice and rats after long-term inhalation of high concentrations of filtered and unfiltered diesel engine emissions. J Appl Toxicol. 1986 Dec; 6(6):383-95.

266 McPherson CW, Van Hoosier GL. Laboratory hamsters. Orlando: Academic Press; 1987.

267 Becci PJ, McDowell EM, Trump BF. The respiratory epithelium. II. Hamster trachea, bronchus, and bronchioles. J Natl Cancer Inst. 1978 Aug;61(2):551-61.

268 Safronetz D, Haddock E, Feldmann F, Ebihara $\mathrm{H}$, Feldmann $\mathrm{H}$. In vitro and in vivo activity of ribavirin against Andes virus infection. PLoS One. 2011;6(8):e23560-23560. Available from: https://www.ncbi.nlm.nih. gov/pubmed/21853152

269 Bethell EJ, Koyama NF. Happy hamsters? Enrichment induces positive judgement bias for mildly (but not truly) ambiguous cues to reward and punishment in Mesocricetus auratus. R Soc Open Sci. 2015 Jul;2(7):140399. Available from: https://www.ncbi.nlm.nih. gov/pubmed/26587255

270 Mapara M, Thomas BS, Bhat KM. Rabbit as an animal model for experimental research. Dent Res J (Isfahan). 2012 Jan;9(1):111-8.

271 Sturgess JM. The mucous lining of major bronchi in the rabbit lung. Am Rev Respir Dis. 1977 May;115(5):819-27.

272 Kamaruzaman NA, Kardia E, Kamaldin N, Latahir AZ, Yahaya BH. The rabbit as a model for studying lung disease and stem cell therapy. Biomed Res Int. 2013;2013: 691830. Available from: https://www.ncbi. nlm.nih.gov/pubmed/23653896

273 Polosa R, Blackburn MR. Adenosine receptors as targets for therapeutic intervention in asthma and chronic obstructive pulmonary disease. Trends Pharmacol Sci. 2009 Oct; 30(10):528-35.
274 Mata JF, Altes TA, Cai J, Ruppert K, Mitzner W, Hagspiel KD, et al. Evaluation of emphysema severity and progression in a rabbit model: comparison of hyperpolarized $3 \mathrm{He}$ and 129Xe diffusion MRI with lung morphometry. J Appl Physiol (1985). 2007 Mar; 102(3):1273-80.

275 Keir S, Page C. The rabbit as a model to study asthma and other lung diseases. Pulm Pharmacol Ther. 2008 Oct;21(5):721-30. Available from: http://www.sciencedirect.com/ science/article/pii/S1094553908000102

276 Kozma C, Macklin W, Cummins LM, Mauer R. Anatomy, physiology and biochemistry of the rabbit. In: Weisbroth R, Kraus AL, editors. The biology of the laboratory rabbit. New York: Academic Press; 1974. p. 49-72.

277 Thorning DR, Howard ML, Hudson LD, Schumacher RL. Pulmonary responses to smoke inhalation: morphologic changes in rabbits exposed to pine wood smoke. Hum Pathol. 1982 Apr;13(4):355-64.

278 Fick RB Jr, Paul ES, Merrill WW, Reynolds HY, Loke JS. Alterations in the antibacterial properties of rabbit pulmonary macrophages exposed to wood smoke. Am Rev Respir Dis. 1984 Jan;129(1):76-81.

279 Hage E. Histochemistry and fine structure of endocrine cells in foetal lungs of the rabbit, mouse and guinea-pig. Cell Tissue Res. 1974 Jun;149(4):513-24.

280 Patronek GJ, Waters DJ, Glickman LT. Comparative longevity of pet dogs and humans: implications for gerontology research. J Gerontol A Biol Sci Med Sci. 1997 May;52(3):B171-8.

281 Chapman RW. Canine models of asthma and COPD. Pulm Pharmacol Ther. 2008 Oct;21(5):731-42. Available from: http:// www.sciencedirect.com/science/article/pii/ S1094553908000084

282 Broccard A, Shapiro RS, Schmitz LL, Adams AB, Nahum A, Marini JJ. Prone positioning attenuates and redistributes ventilator-induced lung injury in dogs. Crit Care Med. 2000 Feb;28(2):295-303.

283 Forbes RB, Murray DJ, Albanese MA. Evaluation of an animal model for teaching fibreoptic tracheal intubation. Can J Anaesth. 1989 Mar;36(2):141-4.

284 Wang PM, Kraman SS. Fractal branching pattern of the monopodial canine airway. J Appl Physiol (1985). 2004 Jun;96(6):2194-9.

285 King RJ, Clements JA. Surface active materials from dog lung. II. Composition and physiological correlations. Am J Physiol. 1972 Sep;223(3):715-26.

286 Cox RA, Burke AS, Soejima K, Murakami K, Katahira J, Traber LD, et al. Airway obstruction in sheep with burn and smoke inhalation injuries. Am J Respir Cell Mol Biol. 2003 Sep;29(3 Pt 1):295-302.

287 Meeusen EN, Snibson KJ, Hirst SJ, Bischof RJ. Sheep as a model species for the study and treatment of human asthma and other respiratory diseases. Drug Discov Today Dis Models. 2009;6(4):101-6.
288 Abraham WM. Modeling of asthma, COPD and cystic fibrosis in sheep. Pulm Pharmacol Ther. 2008 Oct;21(5):743-54.

289 White K, Taylor P. Anaesthesia in sheep. In Pract. 2000;22(3):126-35.

290 Hubbard GB, Langlinais PC, Shimazu T, Okerberg CV, Mason AD. The morphology of smoke inhalation injury in sheep. J Trauma Injury Infect Crit Care. 1991;31(11)147786.

291 Almond GW. Research applications using pigs. Vet Clin North Am Food Anim Pract. 1996 Nov;12(3):707-16.

292 Yahaya B. Understanding cellular mechanisms underlying airway epithelial repair: selecting the most appropriate animal models. Sci World J. 2012;2012:961684.

293 Wemyss-Holden SA, Porter KJ, Baxter P, Rudkin GE, Maddern GJ. The laryngeal mask airway in experimental pig anaesthesia. Lab Anim. 1999 Jan;33(1):30-4.

294 Theisen MM, Maas M, Hartlage MA, Ploner F, Niehues SM, Van Aken HK, et al. Ventral recumbency is crucial for fast and safe orotracheal intubation in laboratory swine. Lab Anim. 2009 Jan;43(1):96-101.

295 Alexopoulos C, Jansson B, Lindholm CE. Mucus transport and surface damage after endotracheal intubation and tracheostomy. An experimental study in pigs. Acta Anaesthesiol Scand. 1984 Feb;28(1):68-76.

296 Plopper CG, Hyde DM. The non-human primate as a model for studying COPD and asthma. Pulm Pharmacol Ther. 2008 Oct; 21(5):755-66. Available from: http://www. sciencedirect.com/science/article/pii/ S1094553908000138

297 Gibbs RA, Rogers J, Katze MG, Bumgarner R, Weinstock GM, Mardis ER, et al. Evolutionary and biomedical insights from the rhesus macaque genome. Science. 2007; 316(5822):222-34.

298 Hyde DM, Hamid Q, Irvin CG. Anatomy, pathology, and physiology of the tracheobronchial tree: emphasis on the distal airways. J Allergy Clin Immunol. 2009 Dec; 124(6 Suppl):S72-7.

299 Cai Y, Sugimoto C, Arainga M, Alvarez X, Didier ES, Kuroda MJ. In vivo characterization of alveolar and interstitial lung macrophages in rhesus macaques: implications for understanding lung disease in humans. J Immunol. 2014 Mar;192(6):2821-9.

300 Plopper CG, Heidsiek JG, Weir AJ, George JA, Hyde DM. Tracheobronchial epithelium in the adult rhesus monkey: a quantitative histochemical and ultrastructural study. Am J Anat. 1989 Jan;184(1):31-40.

301 Herring MJ, Avdalovic MV, Quesenberry CL, Putney LF, Tyler NK, Ventimiglia FF, et al. Accelerated structural decrements in the aging female rhesus macaque lung compared with males. Am J Physiol Lung Cell Mol Physiol. 2013 Jan;304(2):L125-34. 
302 Asgharian B, Price O, McClellan G, Corley R, Einstein DR, Jacob RE, et al. Development of a rhesus monkey lung geometry model and application to particle deposition in comparison to humans. Inhal Toxicol. 2012 Nov;24(13):869-99.

303 Chatila WM, Thomashow BM, Minai OA, Criner GJ, Make BJ. Comorbidities in chronic obstructive pulmonary disease. Proc Am Thorac Soc. 2008 May;5(4):549-55. Available from: https://www.ncbi.nlm.nih. gov/pubmed/18453370

304 van der Molen T. Co-morbidities of COPD in primary care: frequency, relation to COPD, and treatment consequences. Prim Care Respir J. 2010 Dec;19(4):326-34.

305 Sussan TE, Rangasamy T, Blake DJ, Malhotra D, El-Haddad H, Bedja D, et al. Targeting Nrf2 with the triterpenoid CDDOimidazolide attenuates cigarette smoke-induced emphysema and cardiac dysfunction in mice. Proc Natl Acad Sci USA. 2009 Jan; 106(1):250-5

306 Nadziejko C, Fang K, Bravo A, Gordon T. Susceptibility to pulmonary hypertension in inbred strains of mice exposed to cigarette smoke. J Appl Physiol (1985). 2007 May; 102(5):1780-5.

307 Wright JL, Churg A. Effect of long-term cigarette smoke exposure on pulmonary vascular structure and function in the guinea pig. Exp Lung Res. 1991 Nov-Dec;17(6):9971009.

308 Tang K, Wagner PD, Breen EC. TNF- $\alpha$ mediated reduction in PGC-1 $\alpha$ may impair skeletal muscle function after cigarette smoke exposure. J Cell Physiol. 2010 Feb; 222(2):320-7.

309 Stolle K, Ansari S, Berges A, Lietz M, Lebrun $\mathrm{S}$, Schleef R, et al. Cigarette smoke and highfat/high-cholesterol diet induce atherogenesis in ApoE-/--mice by different pathways. Toxicol Lett. 2008;180:S40-1.

310 Bhat TA, Kalathil SG, Bogner PN, Miller A, Lehmann PV, Thatcher TH, et al. Secondhand smoke induces inflammation and impairs immunity to respiratory infections. J Immunol. 2018 Apr;200(8):2927-40.

311 Patel DF, Peiró T, Shoemark A, Akthar S, Walker SA, Grabiec AM, et al. An extracellular matrix fragment drives epithelial remodeling and airway hyperresponsiveness. Sci Transl Med. 2018 Aug;10(455):eaaq0693. Available from: http://stm.sciencemag.org/ content/10/455/eaaq0693

312 Zheng H, Liu Y, Huang T, Fang Z, Li G, He S. Development and characterization of a rat model of chronic obstructive pulmonary disease (COPD) induced by sidestream cigarette smoke. Toxicol Lett. 2009 Sep;189(3): 225-34.

313 He F, Liao B, Pu J, Li C, Zheng M, Huang L, et al. Exposure to ambient particulate matter induced COPD in a rat model and a description of the underlying mechanism. Sci Rep. 2017 Mar;7(1):45666.
314 Wang L, Xu Z, Chen B, He W, Hu J, Zhang $\mathrm{L}$, et al. The role of vascular endothelial growth factor in small-airway remodelling in a rat model of chronic obstructive pulmonary disease. Sci Rep. 2017 Jan;7(1):41202.

315 Nie YC, Wu H, Li PB, Luo YL, Zhang CC, Shen JG, et al. Characteristic comparison of three rat models induced by cigarette smoke or combined with LPS: to establish a suitable model for study of airway mucus hypersecretion in chronic obstructive pulmonary disease. Pulm Pharmacol Ther. 2012 Oct; 25(5):349-56.

316 Zhang $\mathrm{X}$, Zheng $\mathrm{H}$, Zhang $\mathrm{H}$, Ma W, Wang F, Liu C, et al. Increased interleukin (IL)-8 and decreased IL-17 production in chronic obstructive pulmonary disease (COPD) provoked by cigarette smoke. Cytokine. 2011 Dec;56(3):717-25.

317 Karlsson JA, Zackrisson C, Lundberg JM. Hyperresponsiveness to tussive stimuli in cigarette smoke-exposed guinea-pigs: a role for capsaicin-sensitive, calcitonin gene-related peptide-containing nerves. Acta Physiol Scand. 1991 Apr;141(4):445-54.

318 Kubo S, Kobayashi M, Masunaga Y, Ishii H, Hirano Y, Takahashi K, et al. Cytokine and chemokine expression in cigarette smokeinduced lung injury in guinea pigs. Eur Respir J. 2005 Dec;26(6):993-1001.

319 Sun J, Chung KF. Airway inflammation despite loss of bronchial hyper-responsiveness after multiple ozone exposures. Respir Med. 1997 Jan;91(1):47-55.

320 Matsumoto K, Aizawa $\mathrm{H}$, Inoue $\mathrm{H}$, Koto H, Nakano H, Hara N. Role of neutrophil elastase in ozone-induced airway responses in guinea-pigs. Eur Respir J. 1999 Nov; 14(5): 1088-94.

321 Schmidt M, Oldenburger A, Zuidhof A, Elzinga $\mathrm{C}$, Meurs $\mathrm{H}$, Maarsingh $\mathrm{H}$, et al. The $\beta 2$-agonist indacaterol and the anticholinergic glycopyrrolate reduce the constriction of large and small intrapulmonary airways using a guinea pig model of COPD. Am J Respir Crit Care Med. 2016;193:A5840.

322 Tonon J, Cecchini AL, Brunnquell CR, Bernardes SS, Cecchini R, Guarnier FA. Lung injury-dependent oxidative status and chymotrypsin-like activity of skeletal muscles in hamsters with experimental emphysema. BMC Musculoskelet Disord. 2013 Jan;14(1): 39.

323 Giri SN, Hyde DM. Increases in severity of lung damage and mortality by treatment with cyclo and lipoxygenase inhibitors in bleomycin and hyperoxia model of lung injury in hamsters. Pathology. 1987 Apr; 19(2): $150-8$.

324 Mehraban S, Ma S, Liu X, Turino G, Cantor $\mathrm{J}$. The potential role of structurally altered elastic fibers in COPD exacerbation. Am J Respir Crit Care Med. 2019;199:A7432.
325 Coyle J, Page CP, Atkinson L, Sjoerdsma K, Touvay C, Metzger WJ. Modification of allergen-induced airway obstruction and airway hyperresponsiveness in an allergic rabbit model by the selective factor antagonist, BN 52021. J Allergy Clin Immunol. 1989; 84(6 Pt 1):960-7.

326 Gan LL, Wang MW, Cheng MS, Pan L. Trachea relaxing effects and $\beta 2$-selectivity of SPFF, a newly developed bronchodilating agent, in guinea pigs and rabbits. Biol Pharm Bull. 2003 Mar;26(3):323-8.

327 Gozzard N, el-Hashim A, Herd CM, Blake SM, Holbrook M, Hughes B, et al. Effect of the glucocorticosteroid budesonide and a novel phosphodiesterase type 4 inhibitor CDP840 on antigen-induced airway responses in neonatally immunised rabbits. $\mathrm{Br}$ J Pharmacol. 1996 Jul;118(5):1201-8. Available from: https://www.ncbi.nlm.nih.gov/ pubmed/8818344

328 Loke J, Paul E, Virgulto JA, Smith GJ. Rabbit lung after acute smoke inhalation. Cellular responses and scanning electron microscopy. Arch Surg. 1984 Aug;119(8):956-9.

329 Seltzer J, Scanlon PD, Drazen JM, Ingram RH Jr, Reid L. Morphologic correlation of physiologic changes caused by $\mathrm{SO} 2$-induced bronchitis in dogs. The role of inflammation. Am Rev Respir Dis. 1984 May;129(5):790-7.

330 Lee LY, Morton RF, Frazier DT. Influence of nicotine in cigarette smoke on acute ventilatory responses in awake dogs. J Appl Physiol (1985). 1985 Jul;59(1):229-36.

331 Cantor JO. CRC Handbook of animal models of pulmonary disease: volume II. Boca Raton: CRC Press; 2018.

332 Frasca JM, Auerbach O, Parks VR, Jamieson JD. Electron microscopic observations on pulmonary fibrosis and emphysema in smoking dogs. Exp Mol Pathol. 1971 Aug 15(1):108-25. Available from: http://www. sciencedirect.com/science/article/ pii/0014480071900220

333 Martorana PA, Wüsten B, Van Even P, Göbel $\mathrm{H}$, Schaper J. A six-month study of the evolution of papain-induced emphysema in the dog. Am Rev Respir Dis. 1982 Nov; 126(5):898-903. Available from: https:// www.atsjournals.org/doi/abs/10.1164/ arrd.1982.126.5.898

334 Bruun CS, Jensen LK, Leifsson PS, Nielsen J, Cirera S, Jørgensen CB, et al. Functional characterization of a porcine emphysema model. Lung. 2013 Dec;191(6):669-75.

335 Chen P, Hou J, Ding D, Hua X, Yang Z, Cui L. Lipopolysaccharide-induced inflammation of bronchi and emphysematous changes of pulmonary parenchyma in miniature pigs (Sus scrofa domestica). Lab Anim (NY). 2013 Mar;42(3):86-91.

336 Mayse M, Johnson P, Streeter J, Deem M, Hummel J. Targeted lung denervation in the healthy sheep model - A potential treatment for COPD. Eur Respir J. 2014 Sep;44 Suppl 58:943. Available from: http://erj.ersjournals.com/content/44/Suppl_58/P943 
337 Barrow RE, Wang CZ, Cox RA, Evans MJ. Cellular sequence of tracheal repair in sheep after smoke inhalation injury. Lung. 1992; 170(6):331-8

338 Fanucchi MV, Schelegle ES, Baker GL, Evans MJ, McDonald RJ, Gershwin LJ, et al. Immunostimulatory oligonucleotides attenuate airways remodeling in allergic monkeys. Am J Respir Crit Care Med. 2004 Dec; 170(11):1153-7.
339 Schelegle ES, Miller LA, Gershwin LJ, Fanucchi MV, Van Winkle LS, Gerriets JE, et al. Repeated episodes of ozone inhalation amplifies the effects of allergen sensitization and inhalation on airway immune and structural development in Rhesus monkeys. Toxicol Appl Pharmacol. 2003 Aug;191(1):7485.

340 Sterner-Kock A, Kock M, Braun R, Hyde DM. Ozone-induced epithelial injury in the ferret is similar to nonhuman primates. Am J Respir Crit Care Med. 2000 Sep;162(3 Pt 1): 1152-6.

341 Vonarburg C, Loetscher M, Spycher MO, Kropf A, Illi M, Salmon S, et al. Topical application of nebulized human IgG, IgA and IgAM in the lungs of rats and non-human primates. Respir Res. 2019 May;20(1):99.
342 Hyde DM, Miller LA, McDonald RJ, Stovall MY, Wong V, Pinkerton KE, et al. Neutrophils enhance clearance of necrotic epithelial cells in ozone-induced lung injury in rhesus monkeys. Am J Physiol. 1999 Dec 277(6):L1190-8.

343 Polverino F, Doyle-Eisele M, McDonald J, Wilder JA, Royer C, Laucho-Contreras M, et al. A novel nonhuman primate model of cigarette smoke-induced airway disease. Am J Pathol. 2015 Mar;185(3):741-55. Available from: https:/www.ncbi.nlm.nih.gov/pubmed/ 25542772 